\title{
تحديات ضبط جرائم الفساد وتتبع عائداتها فى ضوى الوثائق الدولية والقانون المرى
}

\section{عبده المشرى}

تواجه جهود الكثف عن جرائم الفساد وضبطها هـى والعائدات المتحصلة هنها تحديات كبيرة أمام

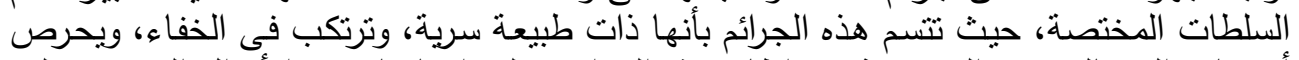

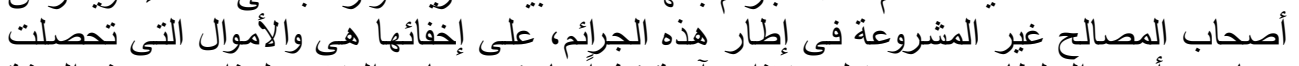

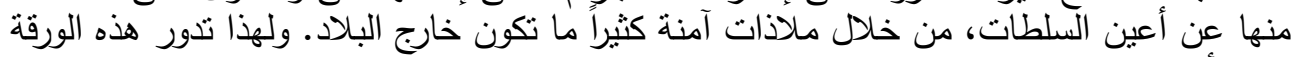

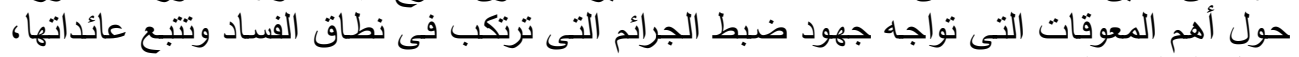
وسبل التغلب عليها.

\section{همدهمة}

لا جرم أن الفسـاد يحرم الثـعوب من الحق فى أن تواصل بحريـة نموها الاقتصـادى، ذلـك الحـق المعتـرف بـه فـى المـادة الأولـى مـن العهـد الـدولى للحقـوق المدنيـة والسياسيـة|(') فالفسـاد آفـة خطيـرة، حيـث يهـدد جميـع أشكـال التتميـة الاقتصاديـة والاجتماعية، ويستنزف الموارد ويضعف إيرادات الدولة، ويقلل من فرص الاستثمار ، ويؤدى إلى ضـف الثقة فى المؤسسات العامـة. ولذلك يعتبر الحق فى مجتمع خال من الفساد، حقًا أساسيًا من حقوق الإنسان، وتعتمد أغلب الحقوق الأخرى وغيرها من القيم الإنسانية المهمة على هذا الحق، وبدونه تفقد هذه الحقوق وهذه القيم الأساسية معناها.

* مدرس، المركز القومى للبحوث الاجتماعية والجنائية. المجلة الجنائية القومية، المجلد الثانى والستون، العدد الأول، ماسس 9 ـ .r. 
وعلى الرغم من السياسات والاستراتيجيات التى ظهرت على مر الزمن على

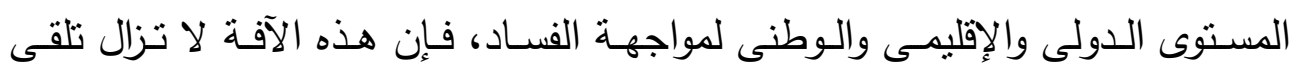

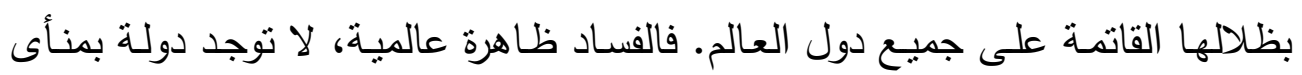

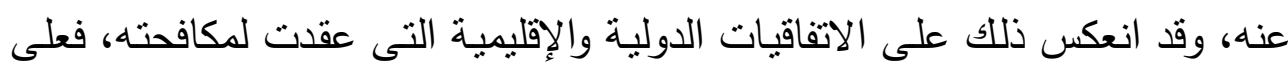

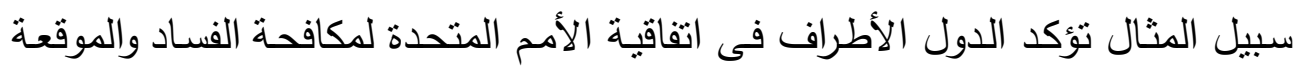

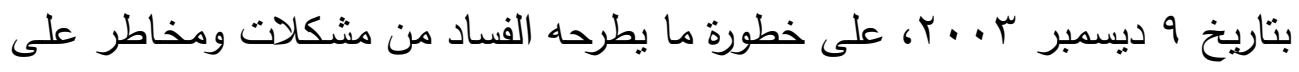
استقرار المجتمعات وأمنها، مما يقوض مؤسسات الديمقراطية وقيمها والقيم الأخلاقية

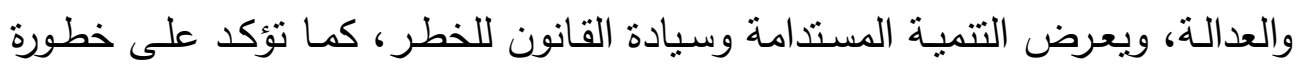

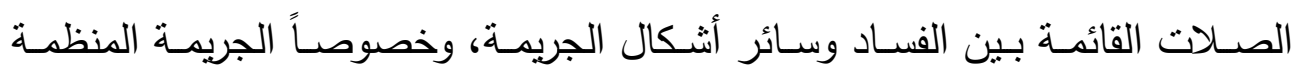
والجريمة الاقتصادية، بما فيها غسل الأموال (الديباجة) (؟).

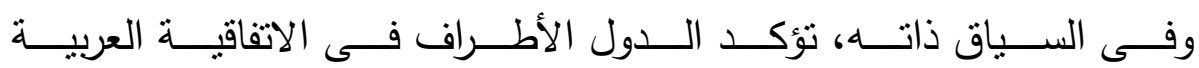

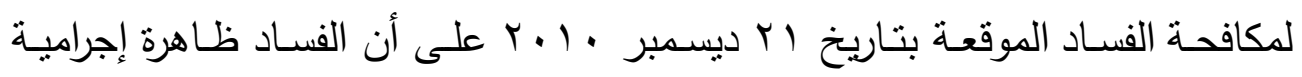

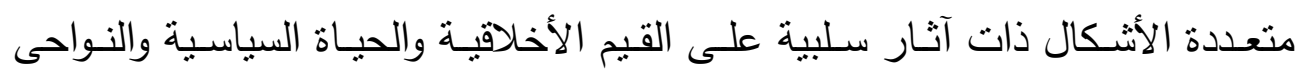

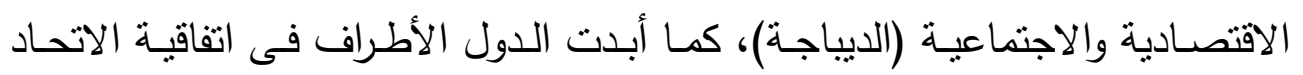

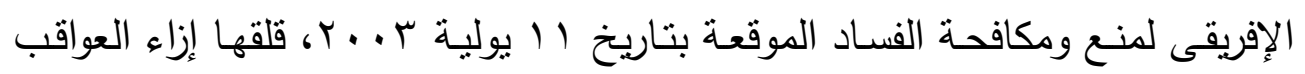

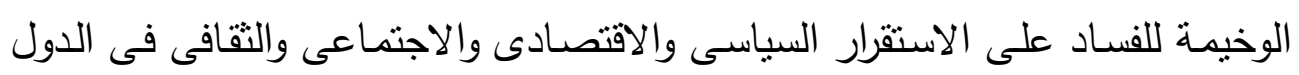

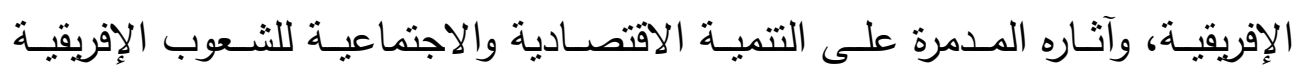

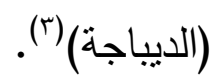


ويتضمن النظام القانونى المصرى، التزاماً دستورياً صريحاً على الدولة بمكافحة

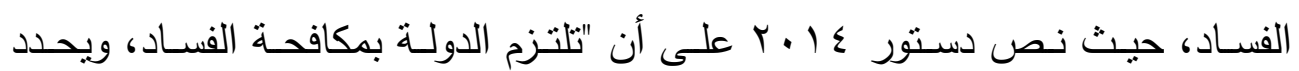

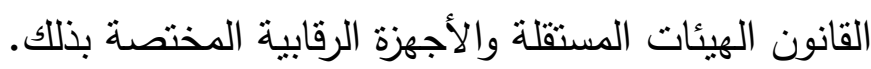

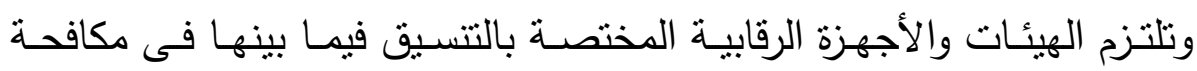

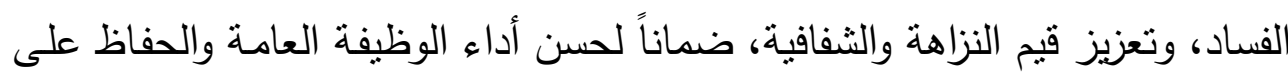

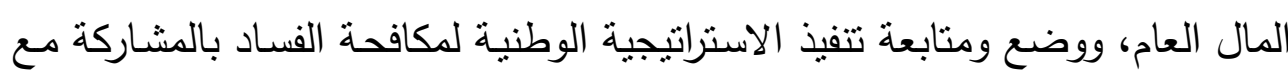
غيرها من الهيئات والأجهزة المعنية، وذلك على النحو الذى ينظمه القانون" (المادة

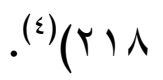

كما تلتزم الدولة بالاتفاقيات الدولية والإقليمية ذات الصلة بمكافحة الفساد التىى

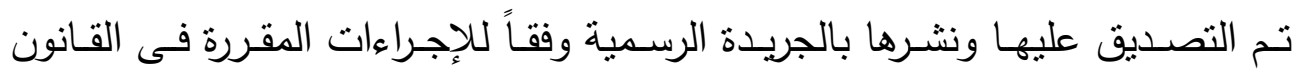

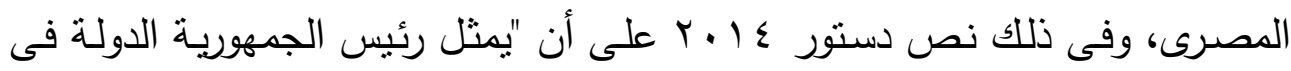

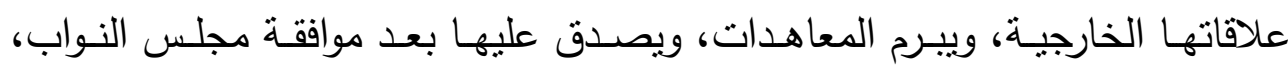

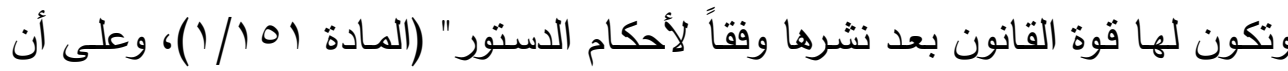
"تلتزم الدولة بالاتفاقيات والعهود والمواثيق الدولية لحقوق الإنسان التى تصدق عليها

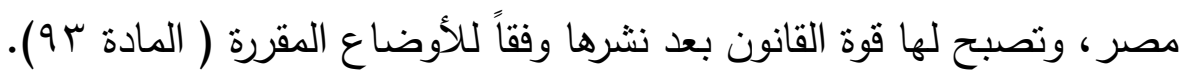

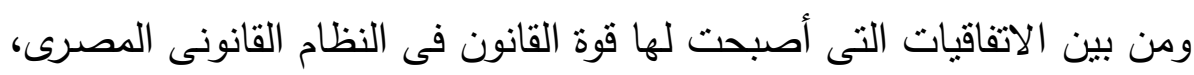

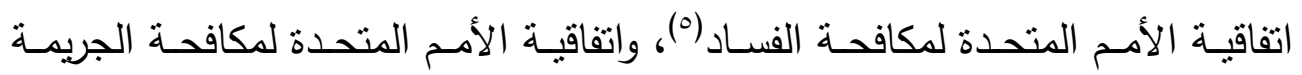

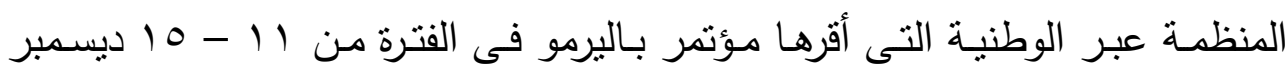

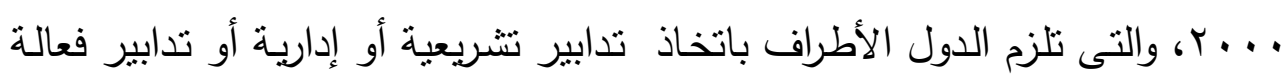

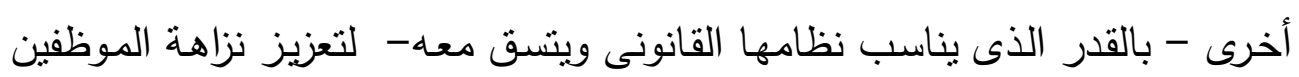


العموميين ومنـع فسـادهم وكثفه والمعاقبة عليه، بمـا فى ذلك منح تلك السلطات استقلالية كافية لردع ممارسة التأثير غير السليم على تصرفاتها (المادة 9)(؟)، وأيضاً الاتفاقية العربية لمكافحة الفساد (v).

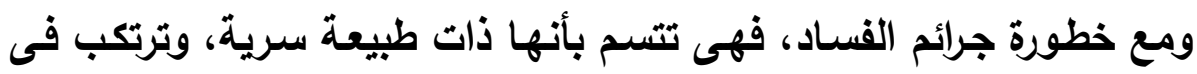

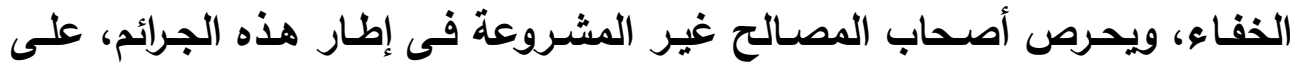

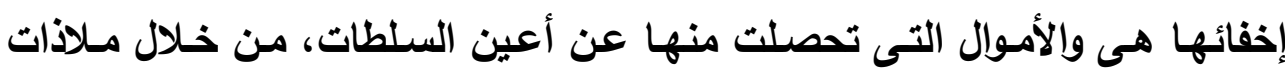

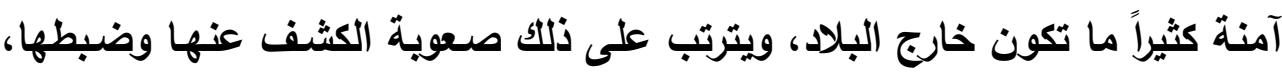

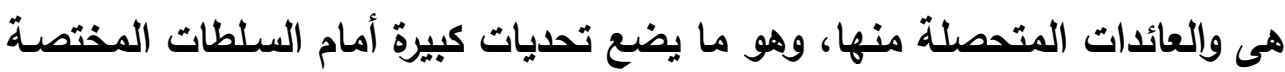
للتظلب على هذه المعوقات. ولهذا تهـف هذه الورقة إلى التعرف على أهم المعوقات التى تواجه جهود ضبط الجرائم التى ترتكب فى نطاق الفساد، وتتبع الأموال التى تحصلت منها، وسبل

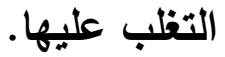

\section{أولاً: هدلول الفساد وأشكاله}

على الرغم من تعدد أثنكال الفساد وصوره، فإنه قد جرت الكثير من المحاولات لوضع مفهوم يؤسس للفساد ويكون معياراً يمكن الاهتداء به فى التعرف على صوره القائمة،

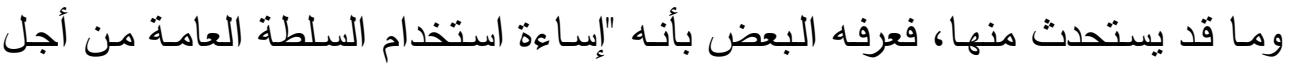

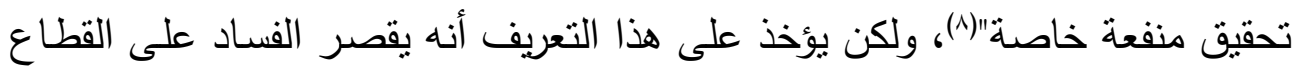
الحكومى والعام دون القطاع الخاص، ولهذا فإن تعريف الفساد بأنه "إساءة استخدام

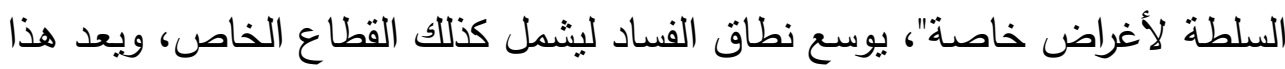
التعريف الأكثر قبولاً على المستوى العالمى (9. 
وقد خلت اتفاقية الأمم المتحدة لمكافحة الفساد من تعريف محدد لمفهوم الفساد،

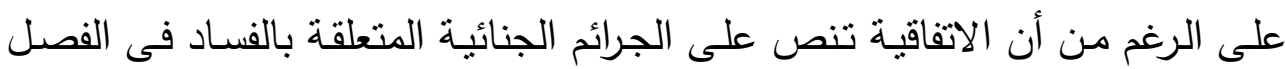

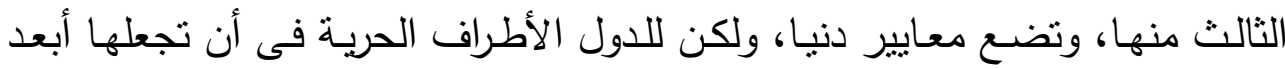

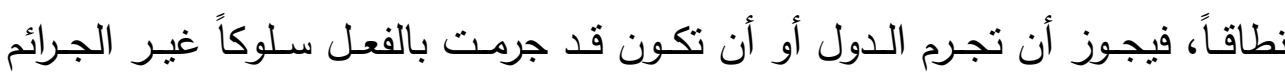

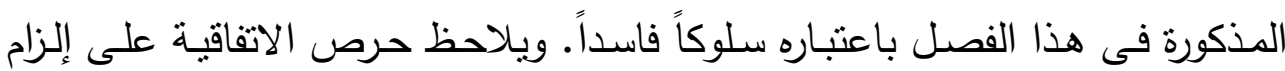
الدول الأطراف بتجريم بعض الأفعال المرتبطة بالفساد، والتى نسهل ارتكاب أعمال التال الفساد وتساعد الجناة على حماية أنفسهر ومكاسبهر غير المشروعة من سلطات إنفاذ

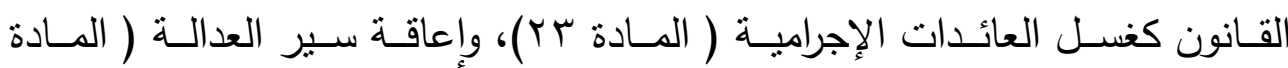
$\cdot()^{(\cdot)}\left(r_{0}\right.$

وأكدت الاتفاقية العربية لمكافحة الفساد، على أن وصف أفعال الفساد المجرمة

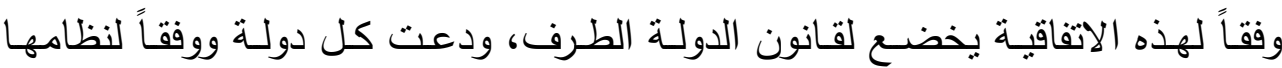
القانونى اعتماد ما قد يلزم من تدابير تتريعية وتدابير أخرى لتجريم الأفعال التالية،

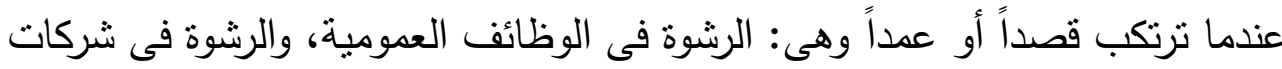

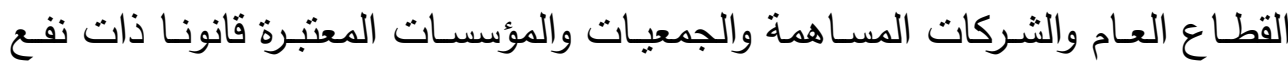

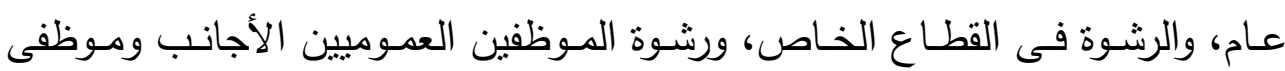

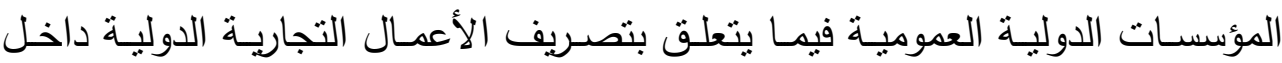

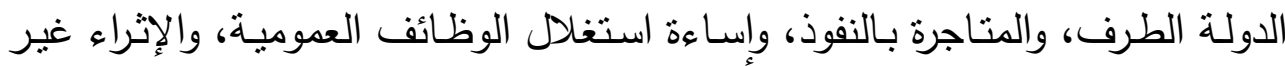

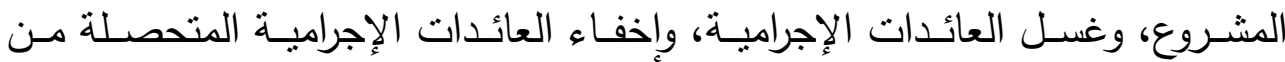

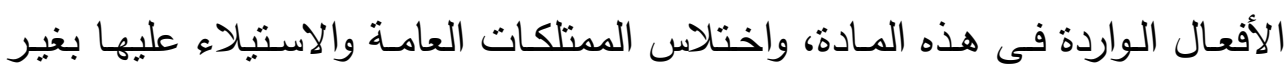


حق، واختلاس ممتلكات الثـركات المسـاهمة والجمعيات الخاصـة ذات النفع العـام والقطاع الخاص، والمشاركة أو الثروع فى هذه الجرائم ( المادة ع).

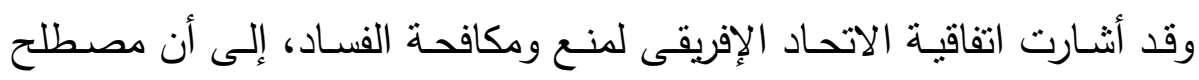

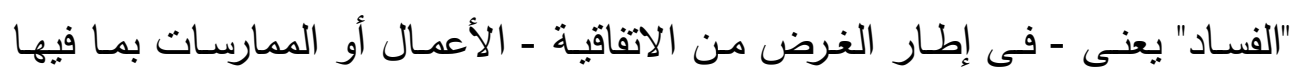

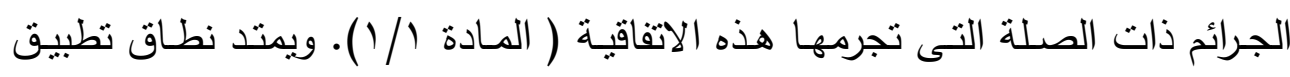

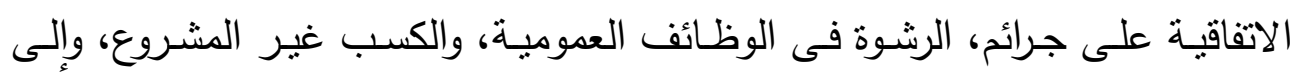

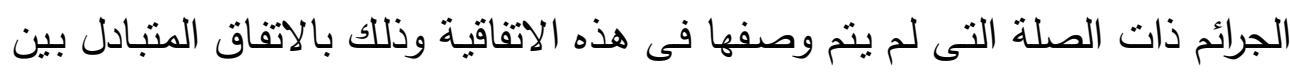

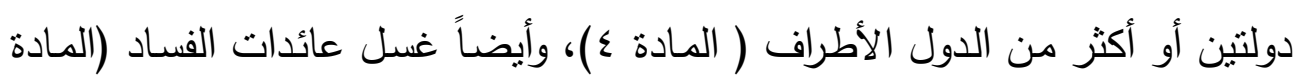

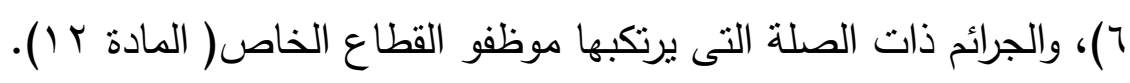

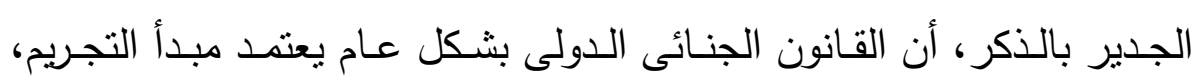

ويترك مساحة واسعة من حرية الحركة للمشرع الوطنى فى تحديد أركان الجرائم (').

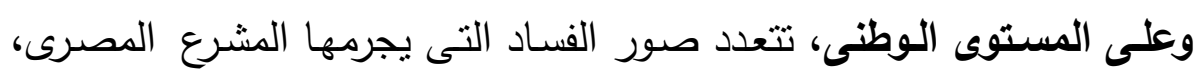

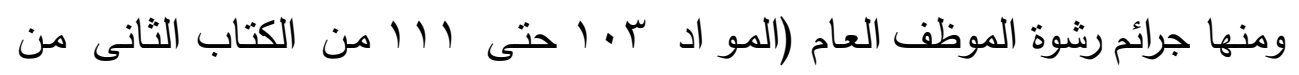

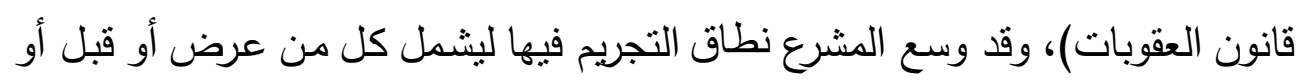

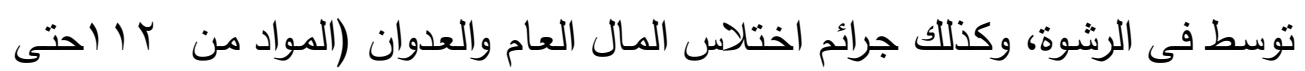
9 (1) من الكتاب الثانى من قانون العقوبات).

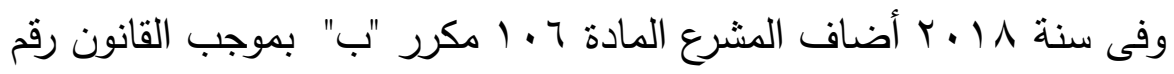

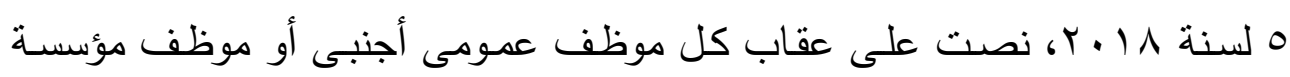

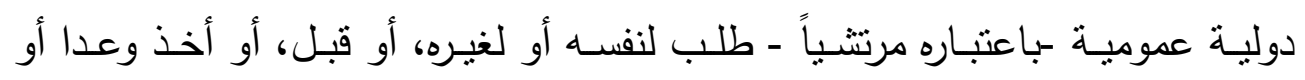

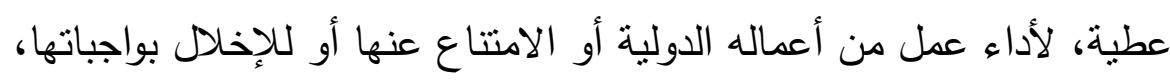




$$
\text { موظف مؤسسة دولية عمومية ولم عقاب كل من عرضل منه ربوة على موظف عمومى أجنبى أو }
$$

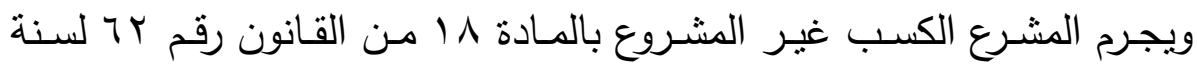

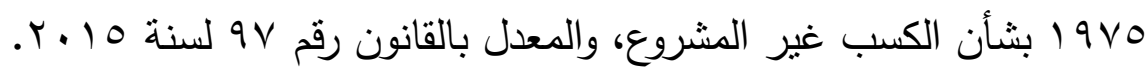

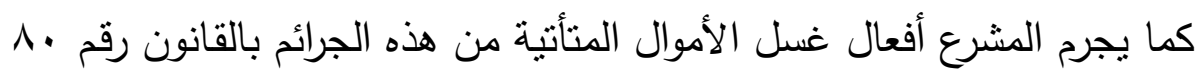

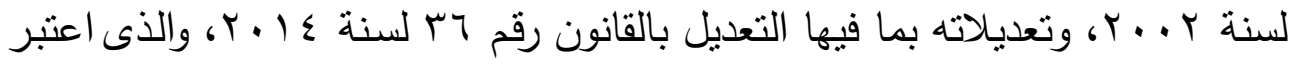

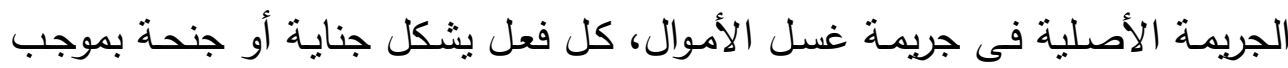

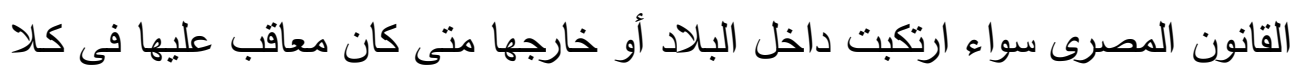

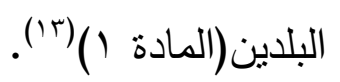
وتجدر الإثشارة، إلى أن المشرع قد استخدم مصطلح "الفساد" فى قانون نتظيم

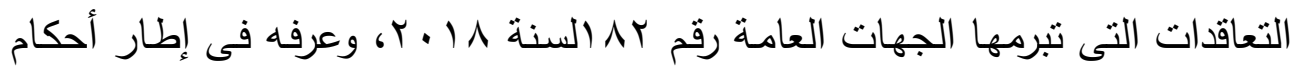

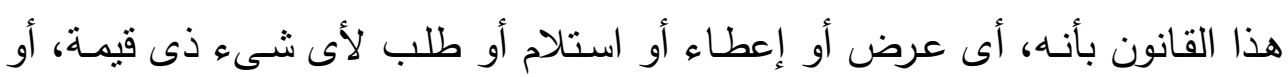

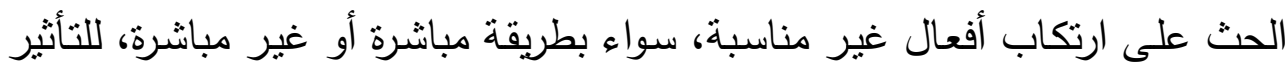

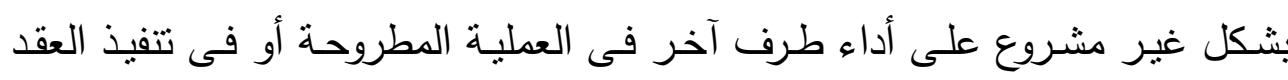

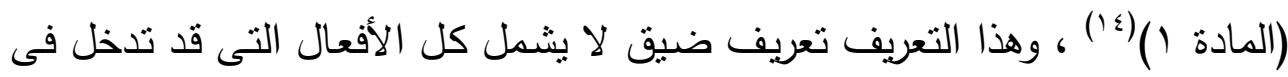

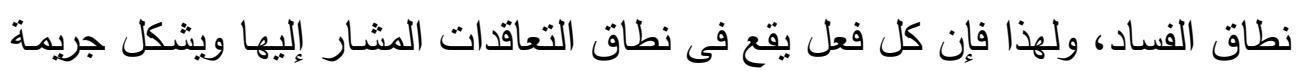
فى قانون العقوبات أو أى قانون آخر فإنه يستوجب الملاحقة فيطاف وعقاب مرتكبيه. 


\section{ثانياً: التحديات المرتبطة بكشف وضبط جرائم الفساد}

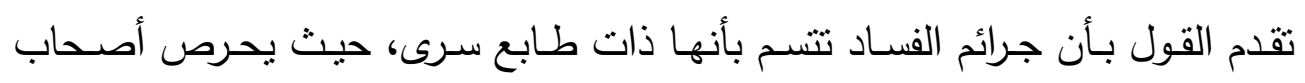

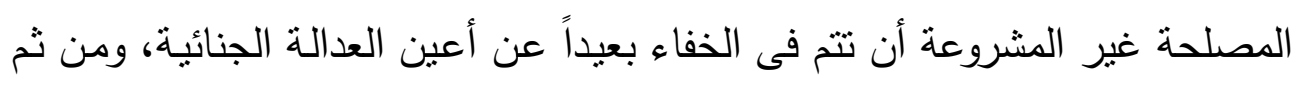
يصعب الكثف عنها فى أغلب حالاتها.

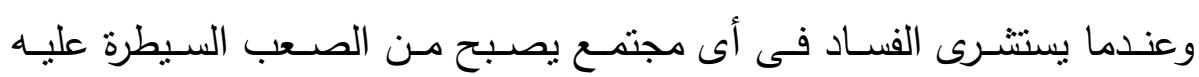

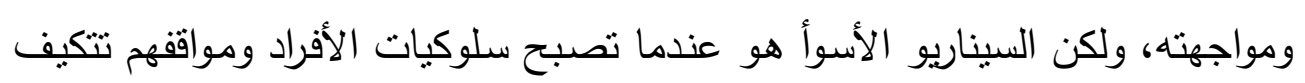

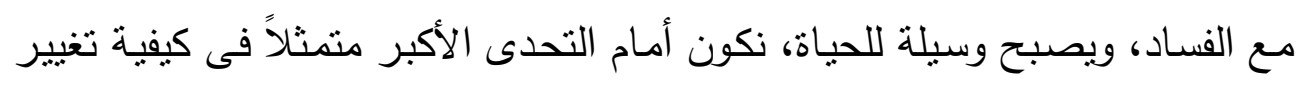

$$
\text { هذه الاتجاهات(10). }
$$

وطبقاً للنتائج الواردة فى تقرير الرأى العام العالمى حول الفساد وتجربة الرشوة،

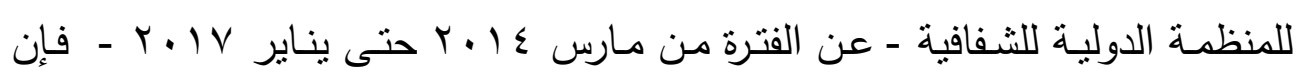

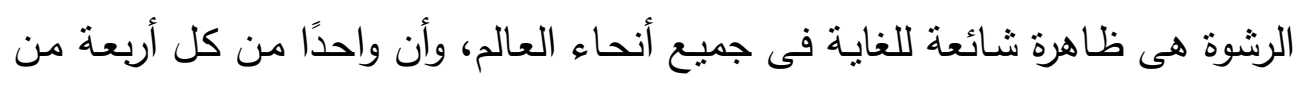
طالبى الخدمات العامة يضطرون لدفع رشوة كل عام (1').

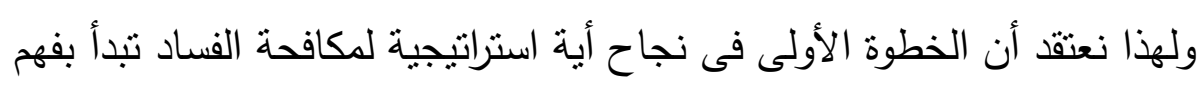

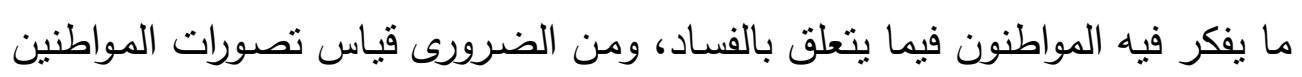

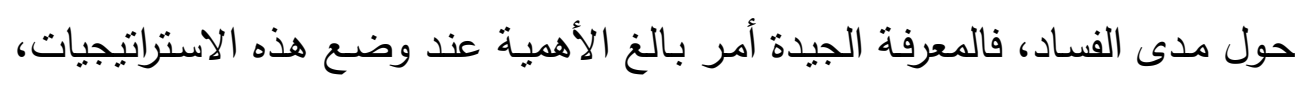

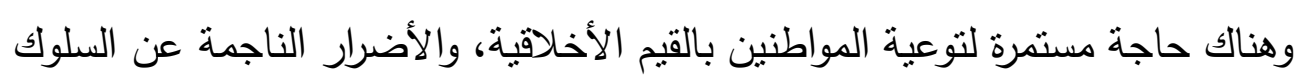

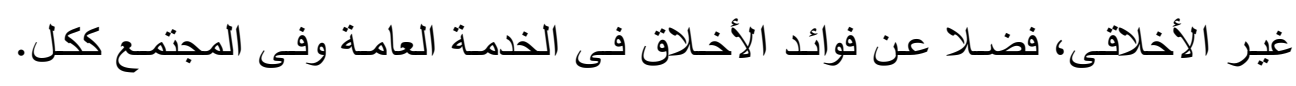

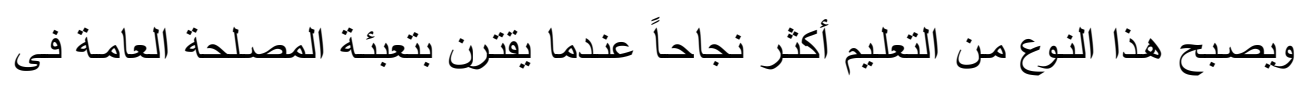
التعامل مع قضايا الفساد، ويمكن تحقيق الوعى العام عن طريق مشاركة المواطنين

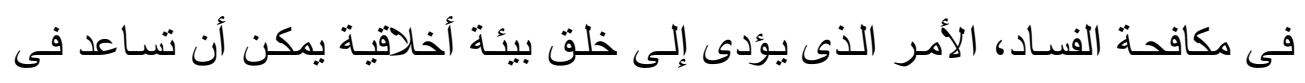


محاربة الفساد(V')، ويمكن أن يشارك الأفراد فى مكافحة الفساد عن طريق الإبلاغ عن

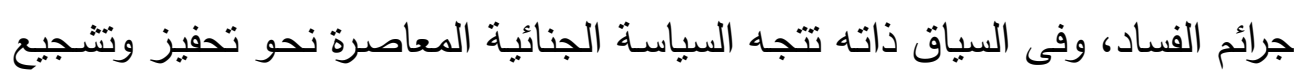

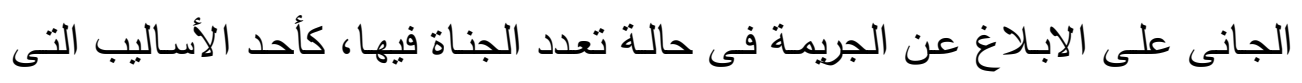
لجأت إليها للكثف عن الجرائم، ومن جانب آخر ، ينطلب التحقيق فى جرائم الفساد الجياد

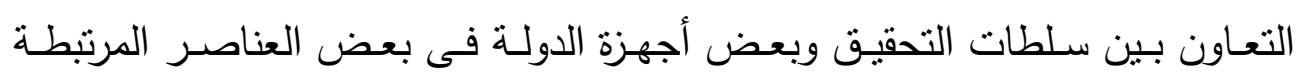

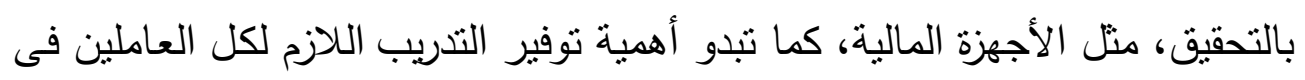

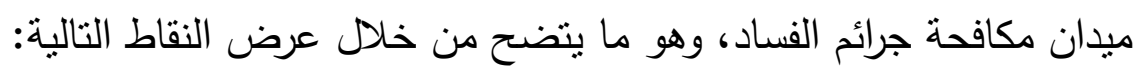

\section{1- الإبلاغ عن حالات الفساد}

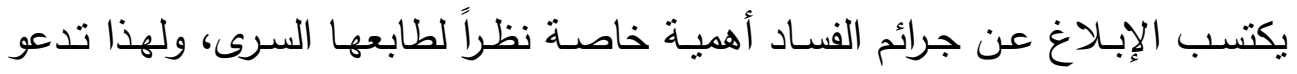

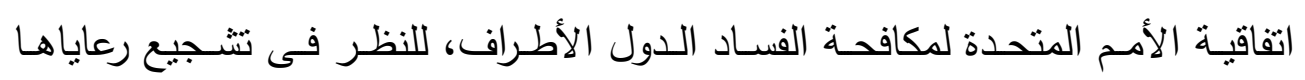

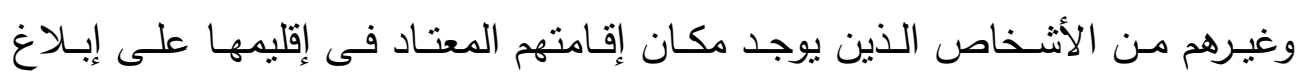

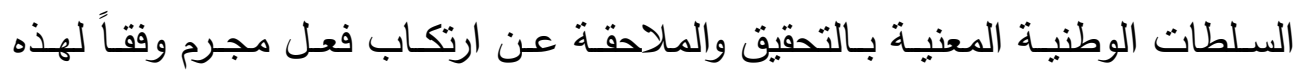

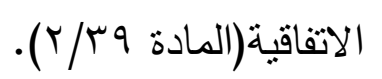

ولعل أبرز الآليات التى يمكن أن تتجع الأفراد على الإبلاغ عن جرائم الفساد

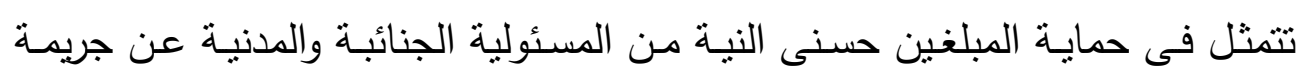

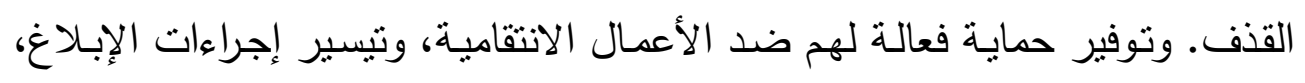
وإتاحة المعلومات وحرية تداولها، رفع الوعى المجتمعى بمخاطر الفساد وهو ما نتتاوله فيما بلى : وانسه 


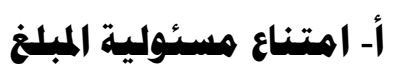

تدعو اتفاققية الأمم المتحدة لمكافحة الفساد، الدول الأطراف إلى النظر فى أن تدخل

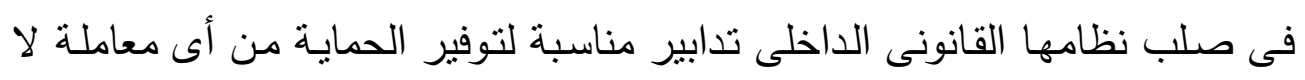

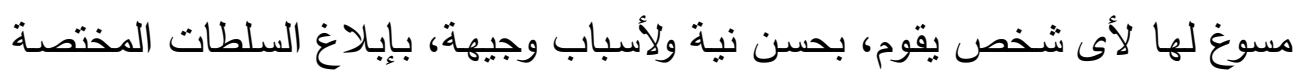

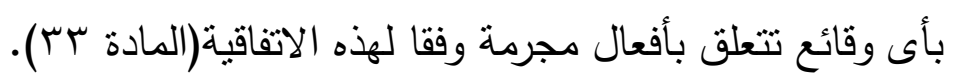

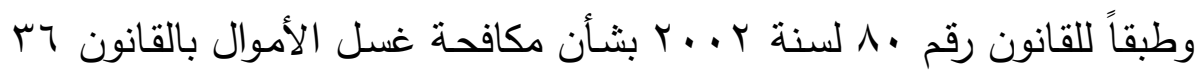

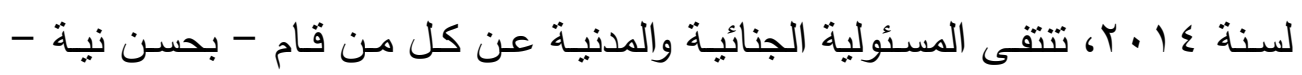

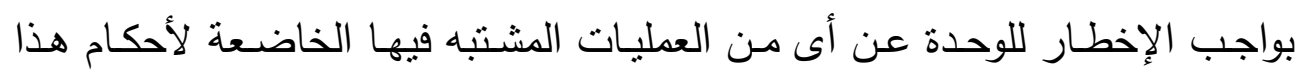

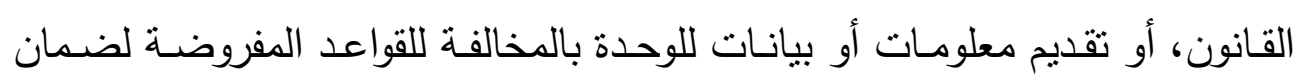

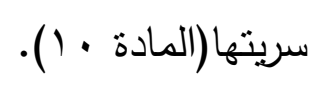

ويشترط لامتتـاع مسئولية المبلـغ توافر حسن النيـة لديه، فإذا كان سيئ النية

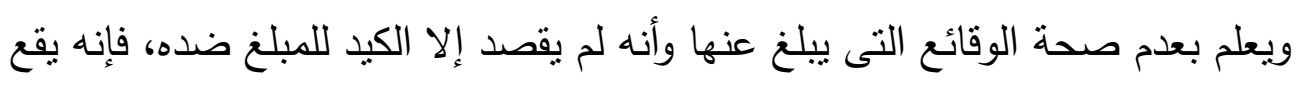
تحت طائلة المسئولية. وفى ذلك يقضى قانون الكسب غير المشروع المصرى بأن،

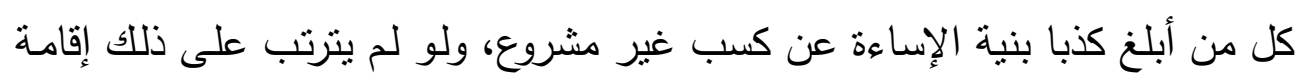

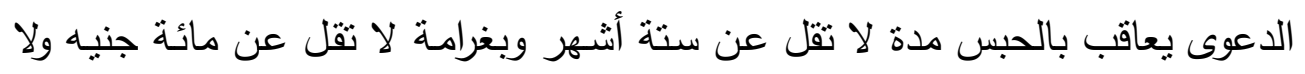
تزيد على خمسمائة جنبه أو بإحدى هاتين العقوبتين (المادةr r).

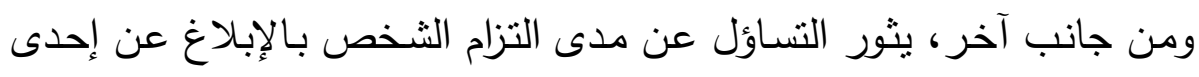

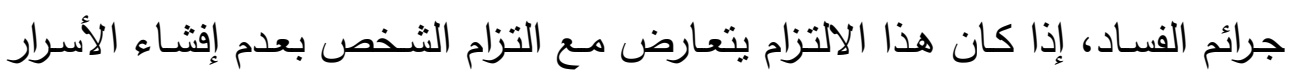
التى أؤتمن عليها بمقتضى مهنته. 
القاعدة فى القانون المصرى، أن إفثاء سر كان مودعاً لدى شخص، وأؤتمن

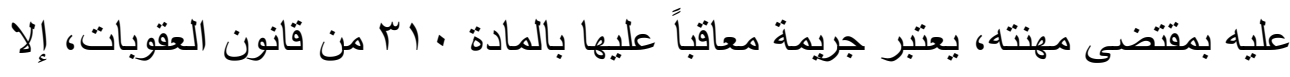

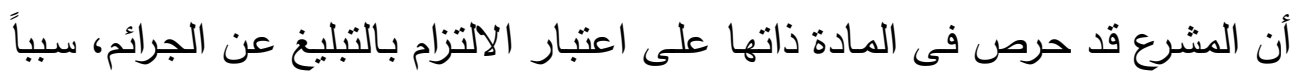

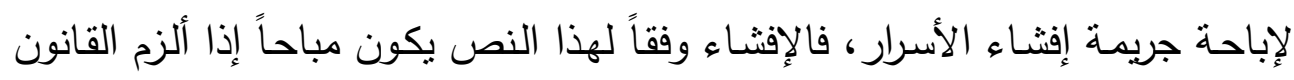

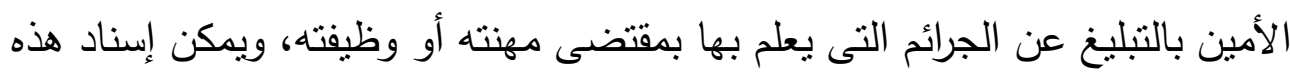

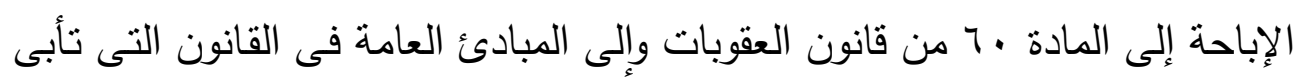

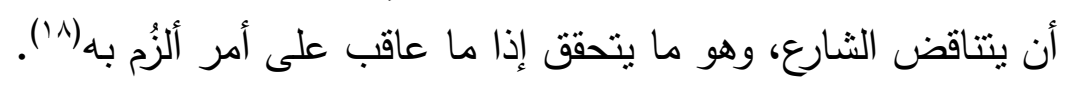

\section{ب- حماية المبلغ هن أى انتقام أو ترهيب هتسمل}

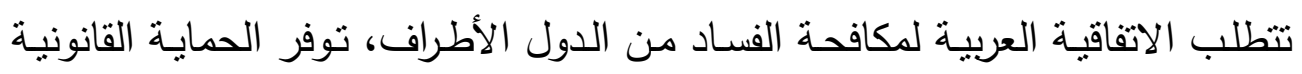

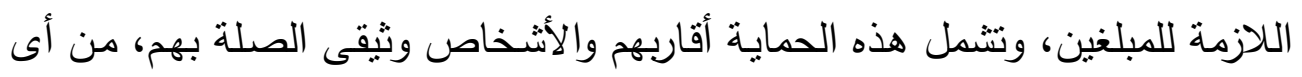
انتقام أو ترهيب محتمل (المادة ـ ( ).

وتلزم اتفاقية الاتحاد الإقريقى لمنع ومكافحة الفساد، الدول الأطراف اعتماد

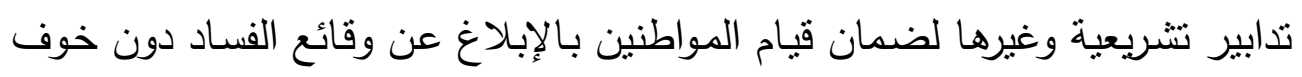

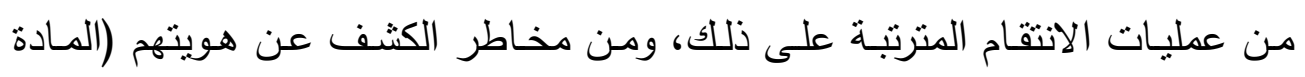
.$(T / 0$

تعتبر حماية المبلغين ذات قيمة دستورية، حيث تضمن دستور ع ا ـ ب النص النص

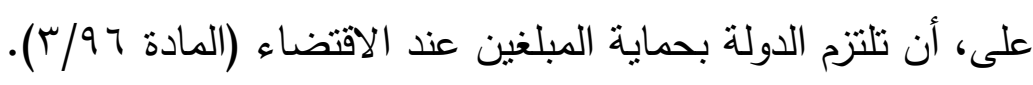

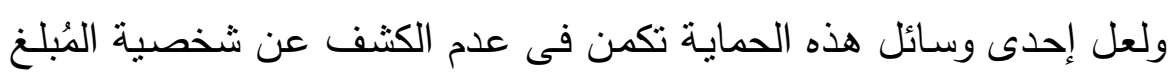

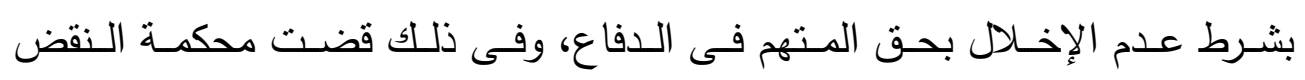


المصرية، أنه لا محل للاستتاد إلى عدم إفصاح الضـابط عن مصدر تحرياته فى

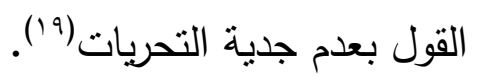

ومـن بـين تـدابير الحمايـة أيضـاً بطـلان جميـع تـدابير الانتقـام (الجـزاءات

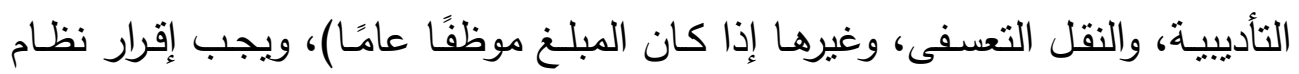

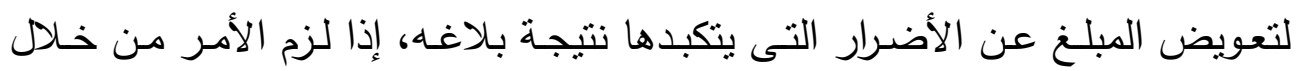
صندوق تعويض يخصص لذلك (r.).

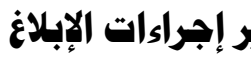

توجب اتفاقية الأمم المتحدة لمكافحة الفساد على كل الدول الأطراف أن تتخذ التدابير

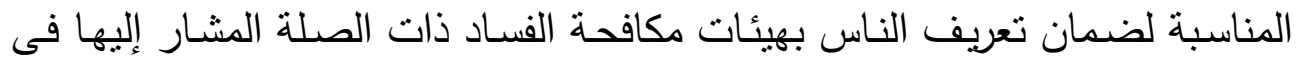

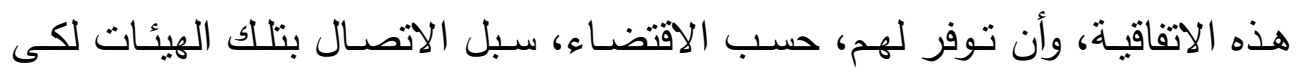

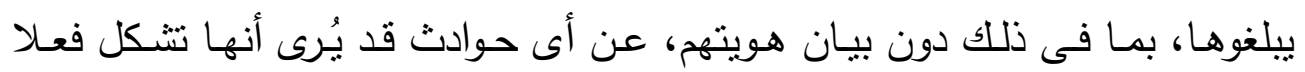

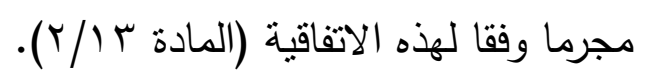

ولا يشترط القانون المصرى شروطاً شكلبة فى البلاغ، فقد يكون تحريرياً مقدماً

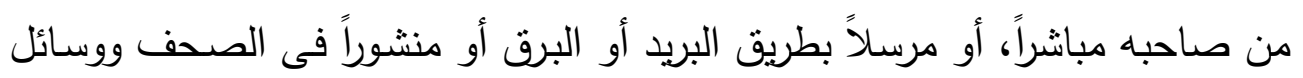

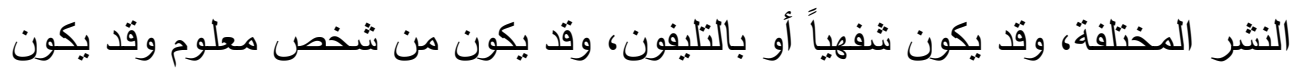

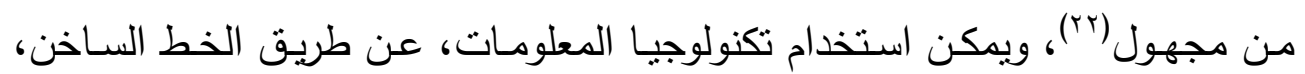
والبريد الإكترونى.

الجدير بالذكر ، أن هيئة الرقابـة الإداريـة المصـرية، توفر عددًا مـن الوسـائل

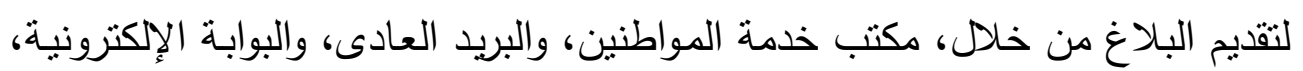

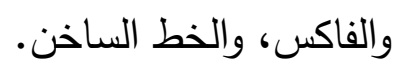




\section{د- إتاحة المعلومهات وحرية تداولها}

تدعو اتفاقية الأمم المتحدة لمكافحة الفساد الدول الأطراف - وفقا للمبادئ الأساسية لقانونها الداخلى ومع مراعاة ضرورة مكافحة الفساد - اعتماد إجراءات أو لوائح تمكن عامـة الناس من الحصول، عند الاقتضـاء، على معلومات عن كيفيـة تتظيم إدارتها العموميـة واشتخالها وعمليات اتخـاذ القرارات فيها، وعن القرارات والصكوك القانونية التى تهم عامة الناس، دع إيلاء المراعاة الواجبة لصون حرمتهم وبياناتهم الشخصية، نشر معلومات يمكن أن تضم تقارير دورية عن مخاطر الفساد فى إدارتها العمومية

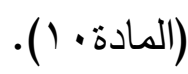

وينص دسـتور ع ا ـ r علـى أن المعلومـات والبيانـات والإحصـاءات والوثائق الرسمية ملك للشعب، والإفصاح عنها من مصادرها المختلفة، حق نكفله الدولة لكل مواطن، وتلتزم الدولة بتوفيرهـا وإتاحتها للمواطنين بشفافية، وينظم القانون ضـوابط الحصول عليها واتاحتها وسريتها وقواعد إيداعها وحفظها والتظلم من رفض إعطائها كما يحدد القانون عقوبة حجب المعلومات أو إعطاء معلومات مغلوطة عمداً. وتلتزم مؤسسات الدولة بإيداع الوثائق الرسمية بعد الانتهاء من فترة العمل بها بدار الوثائق القوميـة وحمايتها وتأمينها من الضياع والتلف، وترميمها، وترقيمها

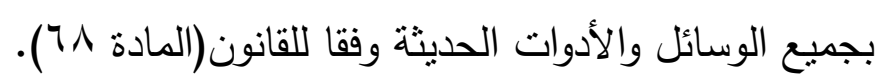
ونص الميثاق الإفريقى لحقوق الإنسان والثـعوب صراحة على أنه، من حق ولى ولى كل فرد أن يحصل على المعلومات ( المادة 9 / ( ). الجدير بالذكر أن، الحق فى الحصول على المعلومات ليس حقًا مطلقًا، ولكن ترد عليه بعض الاستثناءات التى تجد سندها فى مقتضيات حماية حق أو مصلحة 
أخرى أجدر بالرعاية، وفى ذللك يؤكد العهد الدولى للحقوق المدنية والسياسية على أن

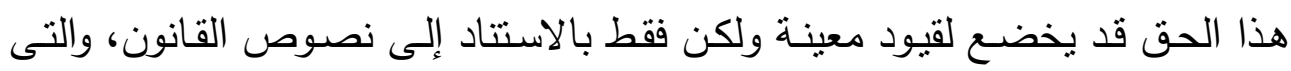

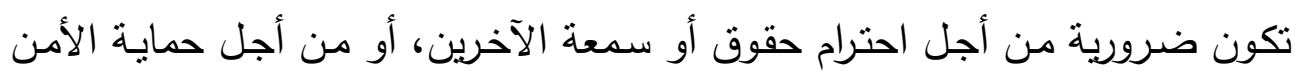
الوطنى أو النظام العام أو الصحة العامة أو الأخلاق (المادة 9 ()).

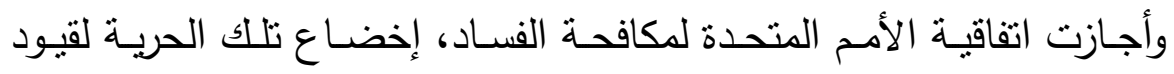

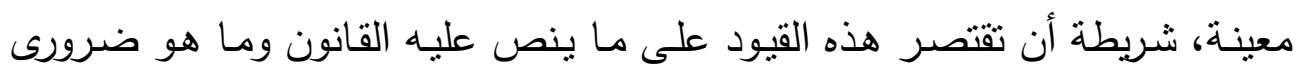

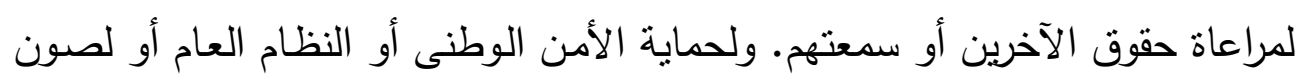

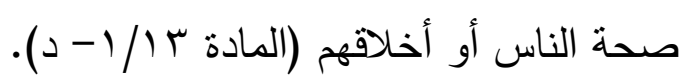

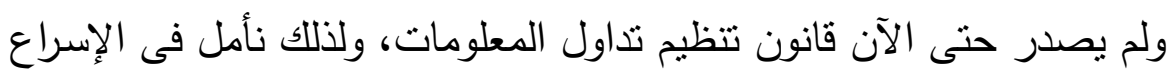
فى إصدار هذا القانون باعنباره التزاماً دستورياً.

هـ - رفع الوعى الجمتمعى بهخاطر الفساد

تتطلب اتفاقية مكافحة الفساد من الدول الأطراف القيام بحملات نوعية يثارك فيها

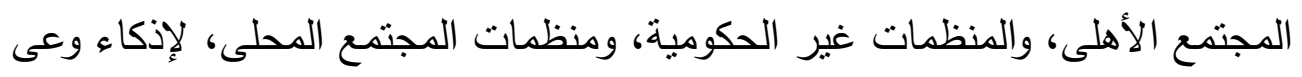

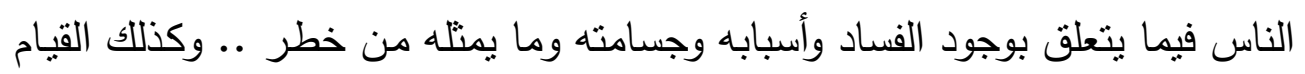

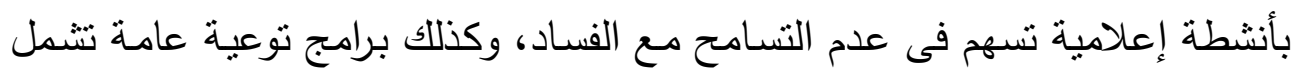

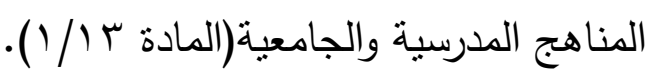
وتتص الاتفاقية العربية لمكافحة الفساد، على أن تتخذ كل دولة طرف تدادية تدابير

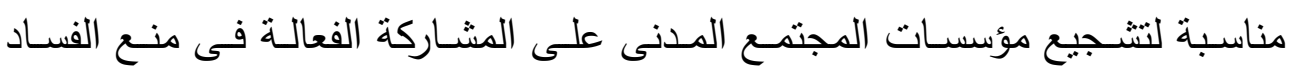

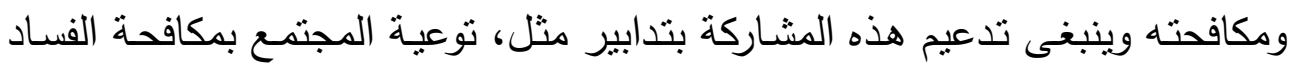

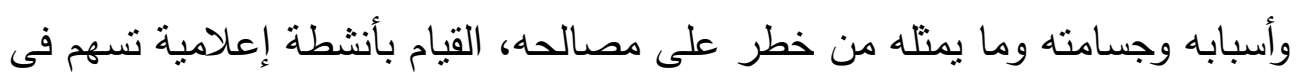


عدم التسامح مـع الفساد، وكذللك برامج توعية تتـمل المنـاهج المدرسية والجامعية. وتعريف الناس بهيئات مكافحة الفساد ذات الصلة المشار إليها في هذه الاتفاقية وأن توفر لهم سبل الاتصال بنلك الهيئات ليتمكنوا من إبلاغها عن أى حوادث قد يرى أنها

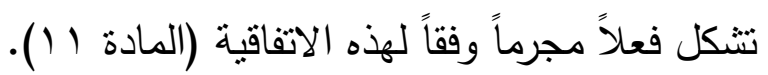

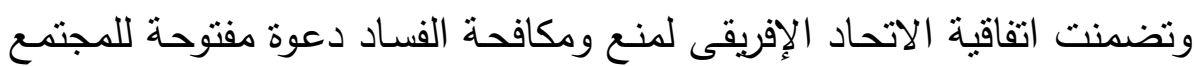

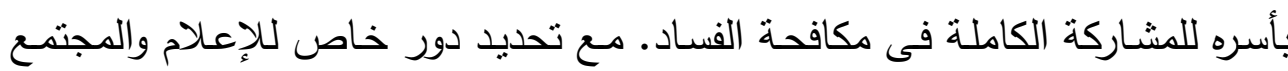
المدنى فى هذا الإطار (المادة r I ).

وفى مصر تقوم اللجنة الوطنيـة التتسيقية لدكافحة الفساد المصرى، بتوعية

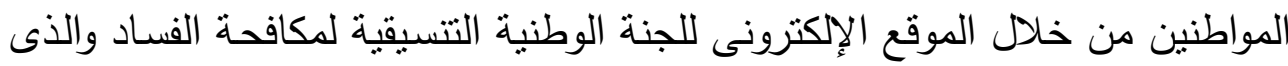

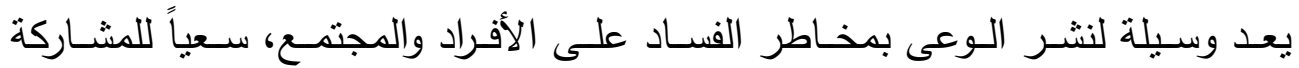

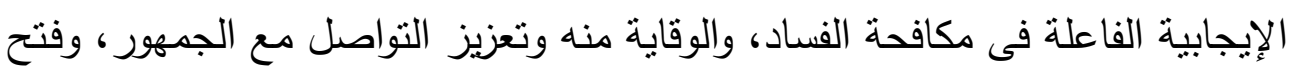

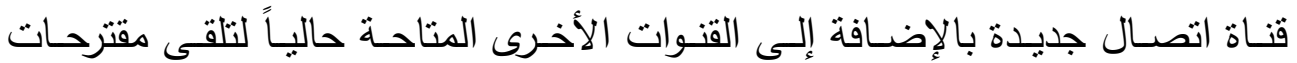

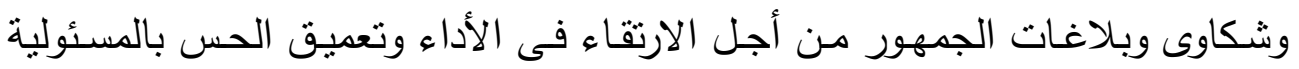
والمشاركة المجتمعية، وتكثيف الجهود فى محاربة آفة الفساد وتجفيف منابعه.

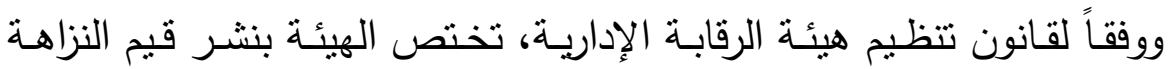

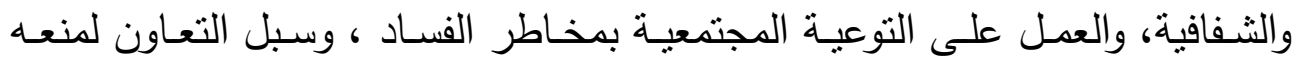

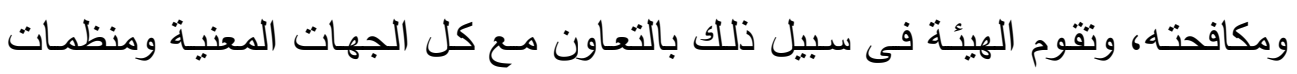
المجتمع المدنى (المادة r/ح). 


\section{r- الإعفاء هن العقاب بوصفة وسيلة للكشف عن جرائم الفساد}

أحد الأسـاليب التى لجأت إليها السياسـة الجنائية للكثف عن الجنه الجرائم ، هو تحفيز

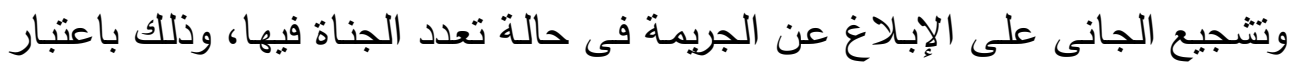

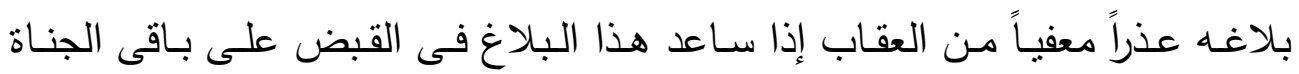
والتوصل إلى عائدات الجريمة. وعلـة العذر المعفى هنـا اعتبارات نفعيـة مستمدة من سياسـة العقاب مبناهـا

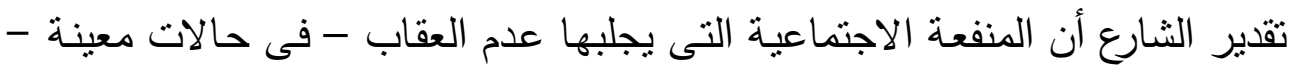
تربو على المنفعة التى يحققها العقاب، فيقرر بناء على ذللك استبعاد العقاب جلباً

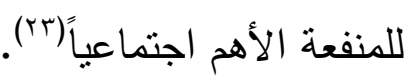

وتدعو اتفاقية الأمم المتحدة لمكافحة الفساد الدول الأطراف، إلى اتخاذ تدابير

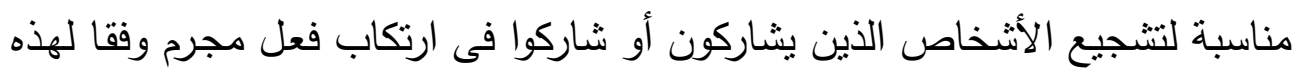

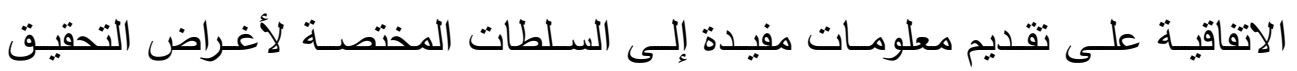

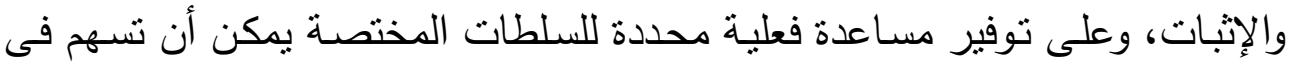
حرمان الجناة من عائدات الجريمة واسترداد تلك العائدات.

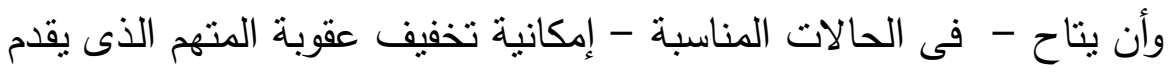
عونا كبيرا فى عمليات التحقيق أو الملاحقة بشأن فعل مجرم وفقا لهذه الاتفاقية.

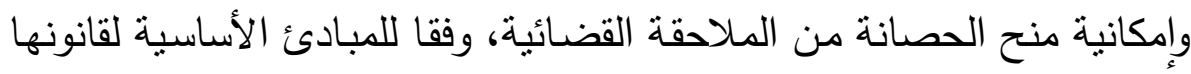

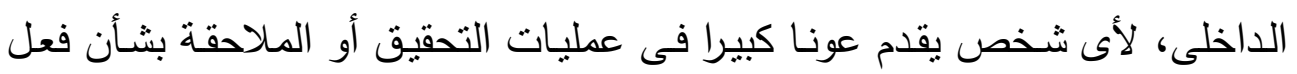

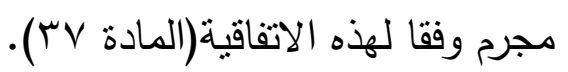


وفى ذلك يعفى قـانون العقوبـات، الراثـى أو الوسيط مـن العقوبـة، إذا أخبر

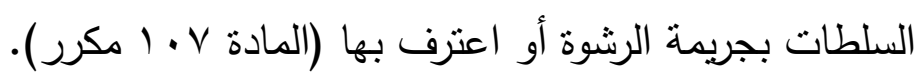

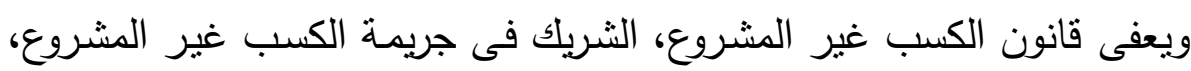

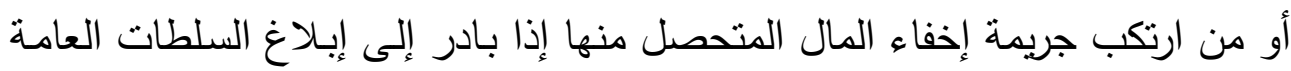

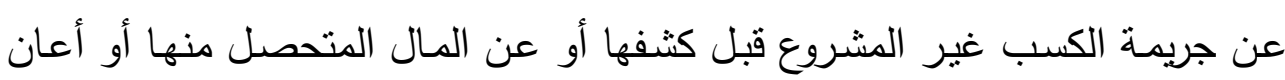

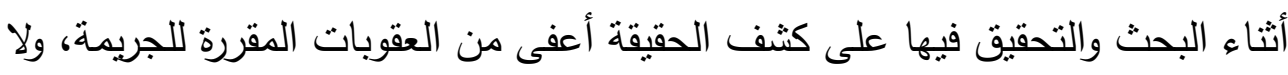
يخل حكم هذه المادة بوجوب الحكم بالرد ( المادة 9 ( ).

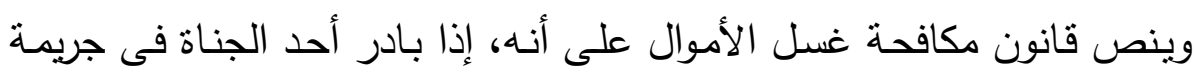

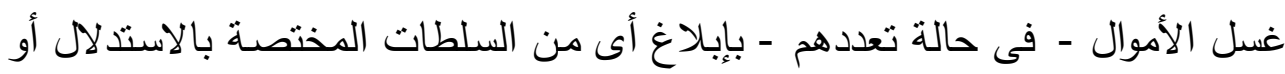

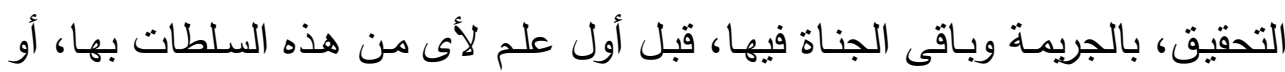

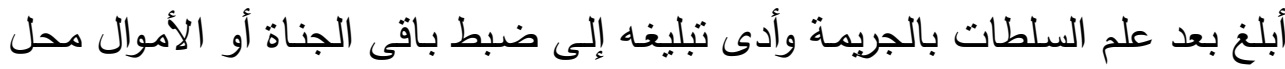

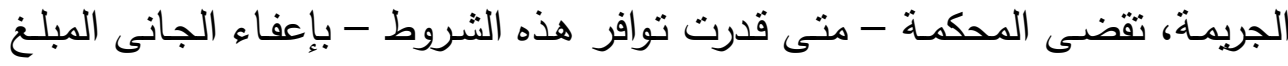

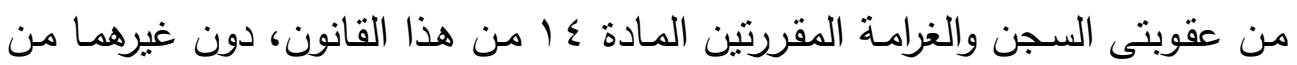

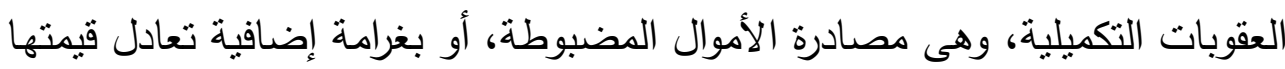
فى حالة تعذر ضبطها أو فى حالة التصرف فيها إلى الغير حسن النية (المادة VI V).

\section{r- التعاون بين السلطات الوطنية}

هناك العديد من الصعوبات التى تواكب إجراءات ملاحقة جرائم الفساد، أبرزها الحاجة التهاتيه

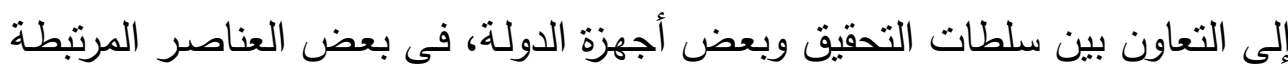
بالتحقيق، منل تتبع عائدات الجناة من هذه الجرائم مع بعض الأجهزة المالية. 
وتتطلب اتفاقيـة الأمم المتحدة لمكافحـة الفسـاد، مـن الدول الأطـراف - وفقـا لقانونها الداخلى - مـا قد يلزم من تدابير لتتـجيع التعاون بين سلطاتها العموميـة، وكذللك موظفيها العموميين، من جانب، وسلطاتها المسئولة عن التحقيق فى الأفعال الإجرامية وملاحقة مرتكبيها، من جانب آخر • ويجوز أن يشمل ذلك التعاون، المبادرة

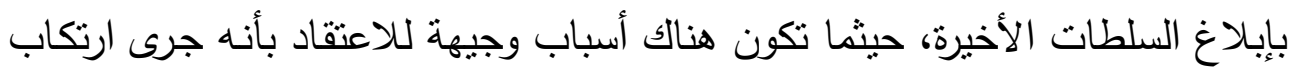

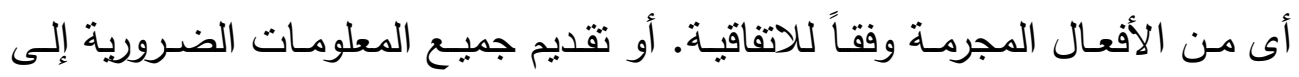
السلطات الأخيرة، بناء على طلإها (المادةمبـ).

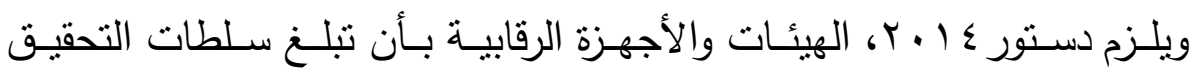

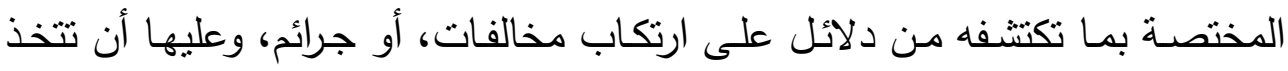

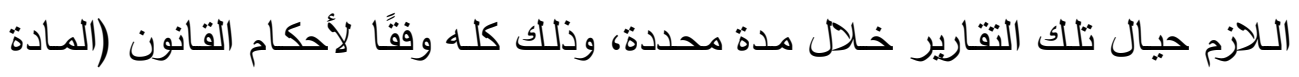
.$(r) \mathrm{V}$ ومن بينها هيئة الرقابة الإدارية، حيث أجرى المشرع تعديلاً على القانون رقم

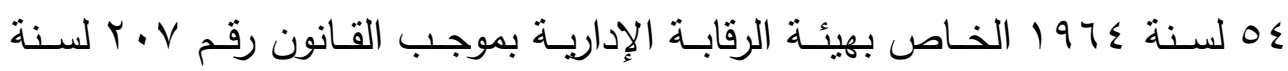

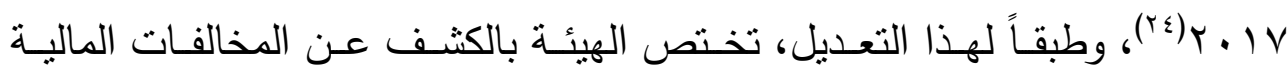

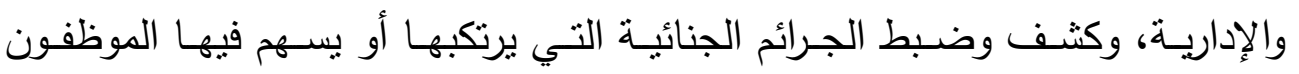

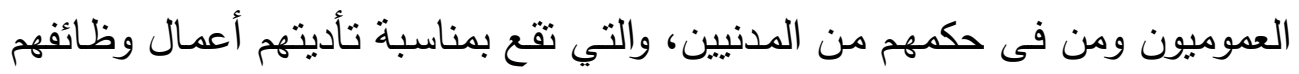
أو بسببها، وكذلك الجرائم التى تنص على سـلامة أداء الوظيفة أو الخدمات العامـة،

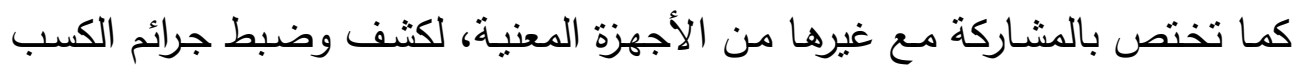

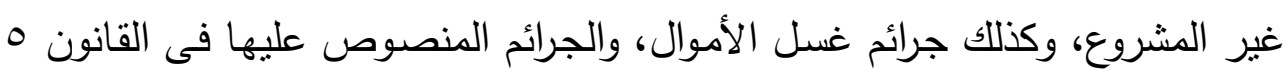




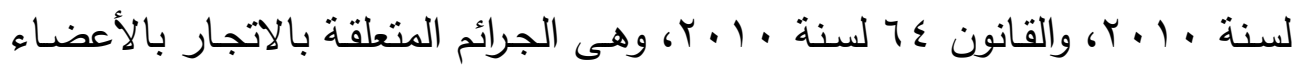

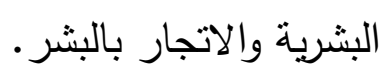

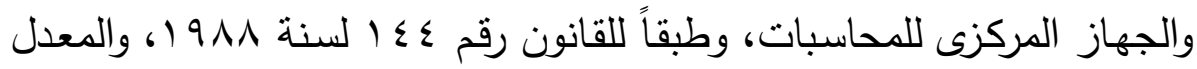
بالقانون 99 ( لسنة 991 (، يعتبر هيئة مستقلة ذات شخصية اعتبارية تتبع رئيس الجمهورية، وتهدف أساسا إلى تحقيق الرقابة على أموال الدولة والأثخاص العامة

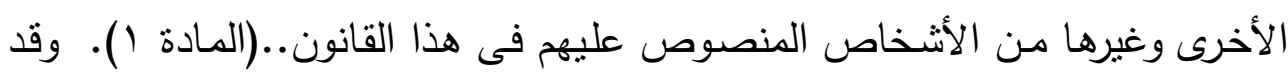

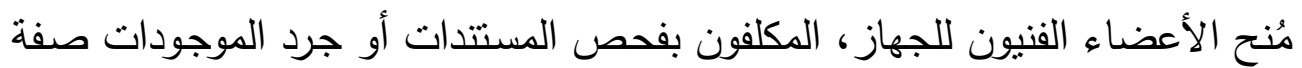

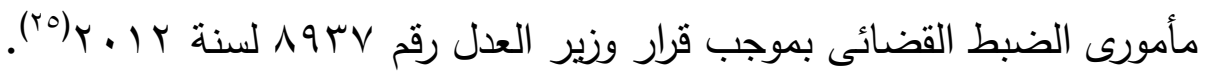
ووحدة غسل الأموال وتمويل الإرهاب بالبنك المركزى، والتى أنشأت بالقانون

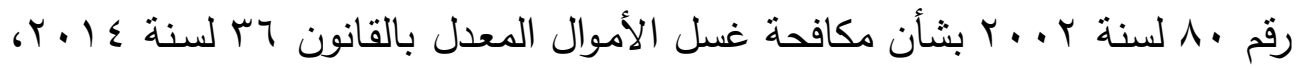
هى وحدة مستقلة ذات طابع خاص لمكافحة غسل الأموال وتمويل الإرهاب تمثل فيها الجهات المعنية(المادة ץ). وتختص بتلقى الإخطارات الواردة من المؤسسات المالية

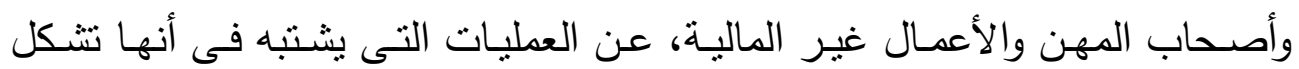

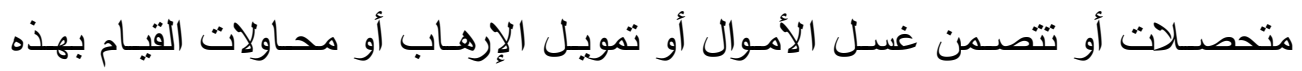

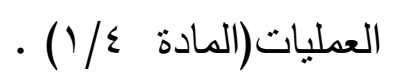
وللعاملين بالوحدة الذين يصدر بتحديدهم قرار من وزير العدل بناء على طلب

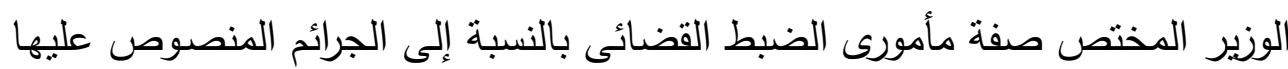
فى هذا القانون والتى تكون متعلقة بأعمال وظائفهم(المادة 7).

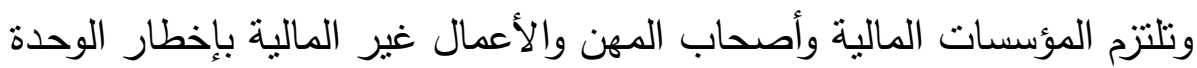

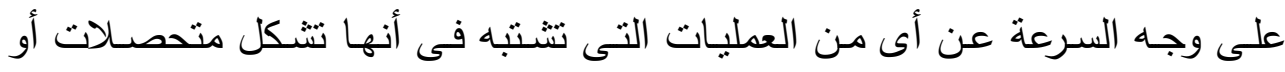


تتضمن غسل الأموال أو تمويل الإرهاب ، أو محاولات القيام بهذه العمليات أيا كانت

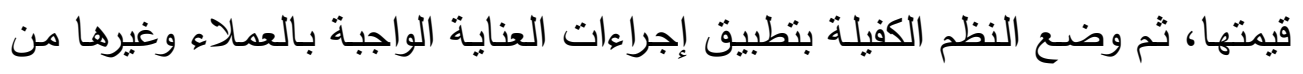
القواعد والإجراءات ذات الصلة بمكافحة غسل الأموال وتمويل الإرهاب التى تصدرها

$$
\text { الوحدة (المادة ^). - (الإجراءات }
$$

ومسن بين هذه الأجهزة إدارة الكسب غيـر المشـروع بـوزارة العدل، المنشأة

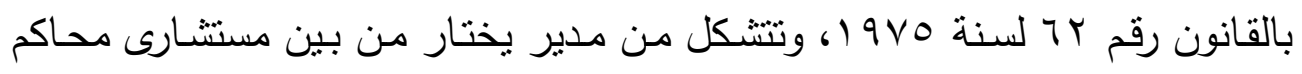

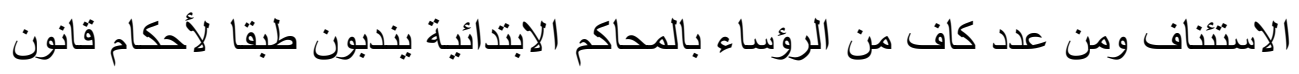
السلطة القضائية.

وكذلك الإدارة العامـة لمباحث الأمسوال العامـة بـوزارة الداخليـة، والتى أنثــت

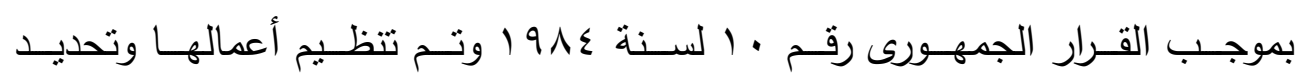

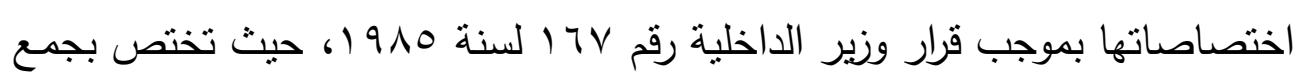

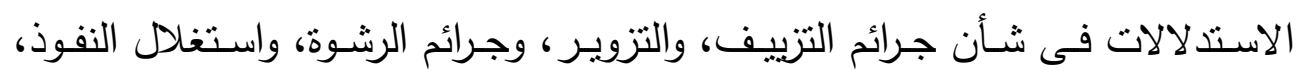

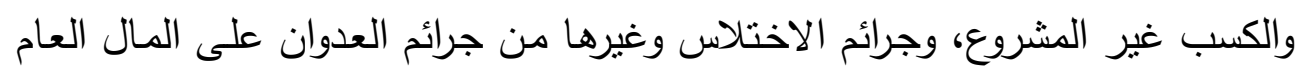

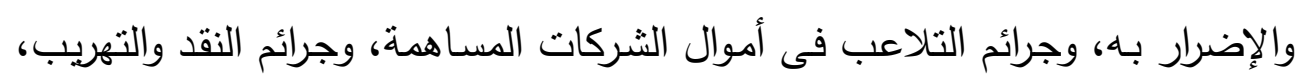
وجرائم توظيف الأموال وغسل الأموال.

ولا شك فى أن فاعلية إجراءات مكافحة الفساد تقتضى تنسيق الجهود بلين

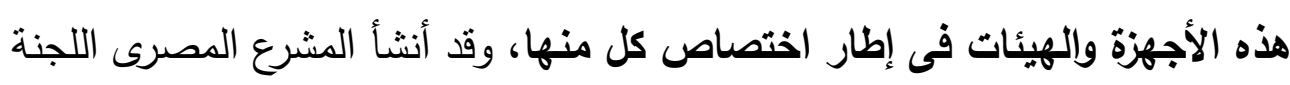

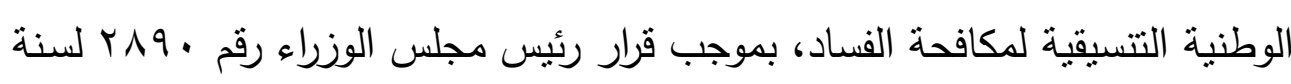

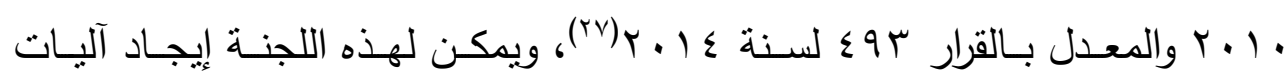

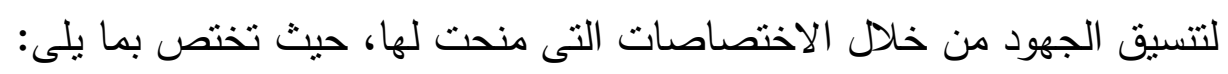


1- تفعيل الإنفاذ الفعلى لأحكام اتفاقيـة الأمم المتحدة لمكافحـة الفسـاد والاتفاقيات

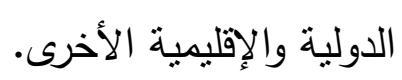

r- صياغة رؤية مصرية موحدة يتم التعبير عنها فى الدحافل الدولية.

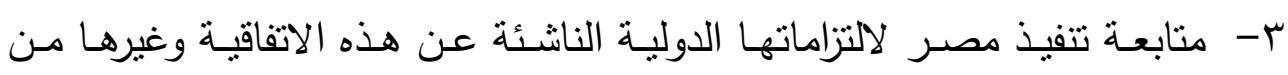

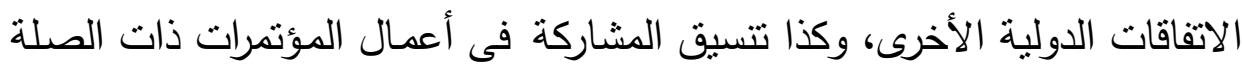
والفرق والمجموعات المنبثقة عنها.

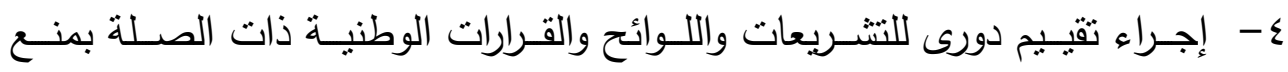
ومكافحة الفساد والوقاية منه، وتقرير مدى كفايتها وتوافقها مع نصوص دور الاتفاقيات الدولية التى وقعت عليها مصر.

\section{ه- التدريب فى هجال هكافحة الفساد}

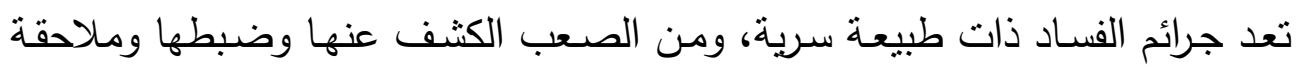
مرتكبيها، ويصعب كذللك التحقيق فيها - حسبما تقدم ذكره - ولهذا يتعين توفير

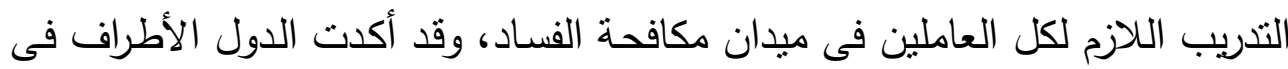

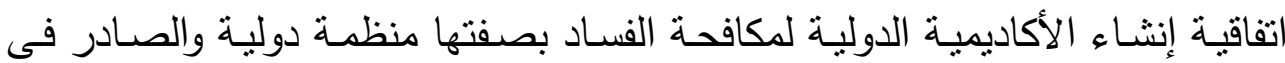

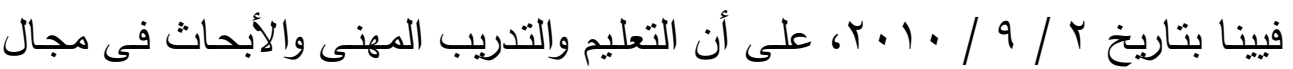

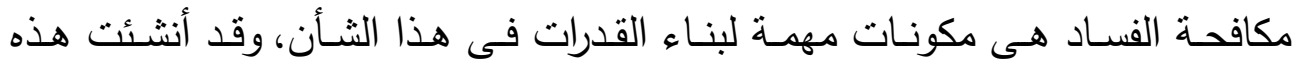

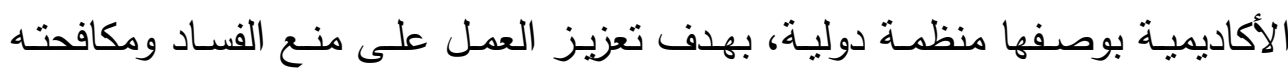

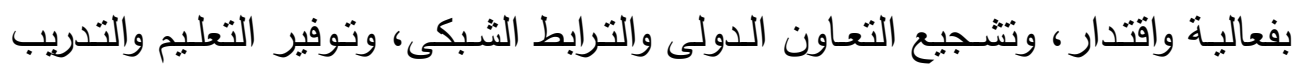

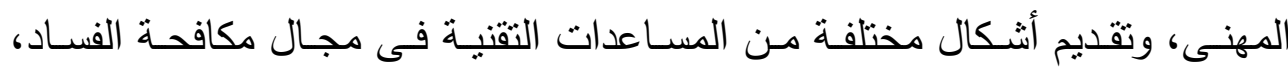
والاضطلاع بأبحاث فى كل جوانب الفساد وتيسبر إجراء مثل تلك الأبحاث. 
وتلزم الاتفاقية الأكاديمية بالحرص فيما تضطلع به من أنشطة على مراعاة مبدأ

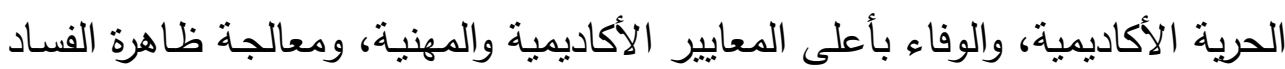

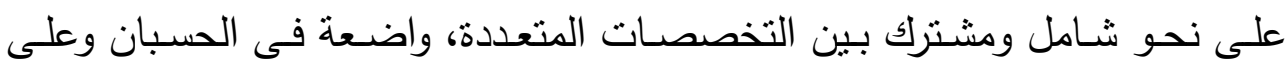

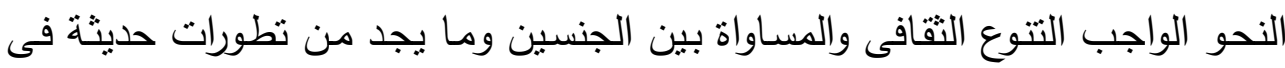
ميدان الفساد على الصعيدين العالمى والإقليمى( المادة r)(r^). تتطلب اتفاقية الأمم المتحدة لمكافحة الفساد من الدول الأطراف القيام - بالقدر اللازم - باستحداث أو تطوير أو تحسين برامج تدريب خاصـة لموظفيها المسئولين

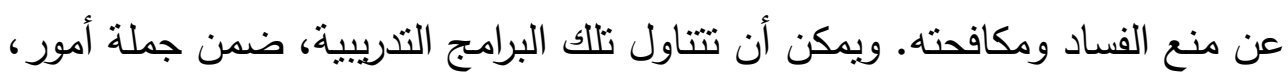

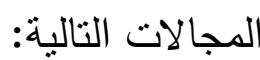
- وضـع تدابير فعّالة لمنع الفساد وكثفه والتحقيق فيه أو المعاقبة عليه ومكافحته، بما فى ذلك استعمال أساليب جمع الأدلة والتحقيق. - بناء القرات في مجال صوغ وتخطيط سياسة استراتيجية لمكافحة الفساد. - تدريب السلطات المختصـة على إعداد طلبات بثأن المساعدة القانونية المنبادلة تفى بمنطلبات الاتفاقية. - تقييم وتدعيم المؤسسات وإدارة الخدمات العمومية وإدارة الأموال العمومية، بما فى لئي ذللك المشتريات العمومية، والقطاع الخاص.

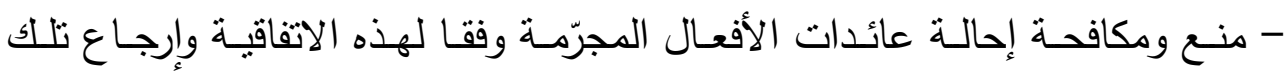

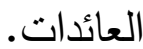
- كثف وتجميد إحالة عائدات الأفعال المجرّمة وفقا لهذه الاتفاقية. 
- مراقبة حركة عائدات الأفعال المجرّمة وفقا لهذه الاتفاقية والأساليب المستخدمة في

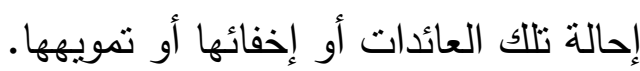

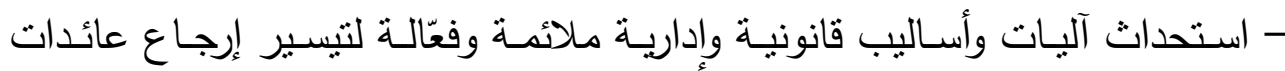
الأفعال المجرّمة وفقا لهذه الاتفاقية. - الطرائـق المتبعـة فـى حمايـة الضــايا والثــهود الـذين يتعـاونون مـع السـلطات القضائية. - التدريب على تطبيق الللائح الوطنية والدولية وعلى اللغات.

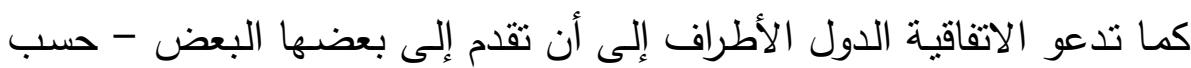

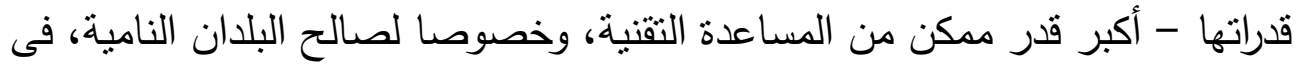
خططها وبرامجها الرامية إلى مكافحة الفساد، بما فى ذلك الدعم المادى والتدريب فى التى المجالات المشار سلفاً، والتدريب والمساعدة، وتبادل الخبرات والمعارف المتخصصة ذات الصـلة التى ستيسـر التعـاون الدولى بين الدول الأطـراف فى مجـالى نسـليم المجرمين والمساعدة القانونية المتبادلة. وتعزيز الجهود الرامية إلى تحقيق أقصى زيادة ممكنة فى الأنشطة والتدريبية

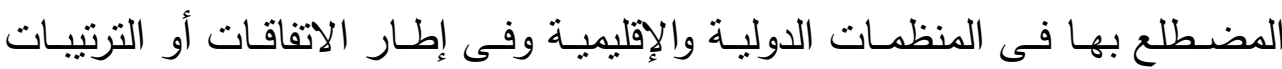
الثنائية والمتعددة الأطراف ذات الصلة. ومساعدة بعضها البعض، عند الطلب، على إجراء تقييمات ودراسات وبحوث بشأن أنواع الفساد وأسبابه وآثاره وتكاليفه فى بلدانها، لكى تضعى، بمشاركة السلطات إنداء المختصة والمجتمع، استراتيجيات وخطط عمل لمكافحة الفساد. 
وتيسيراً لاسترداد عائدات الأفعال المجرمـة وفقا لهذه الاتفاقيـة، يجوز للدول

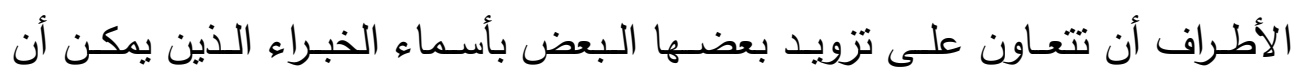

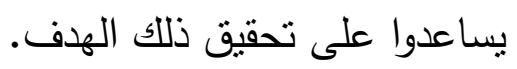

واسـتخدام المـؤتمرات والحلقـات الدراسـية الإقليميـة، ودون الإقليميـة، والدوليـة

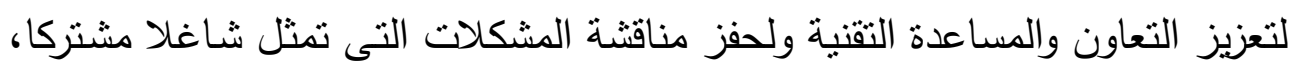

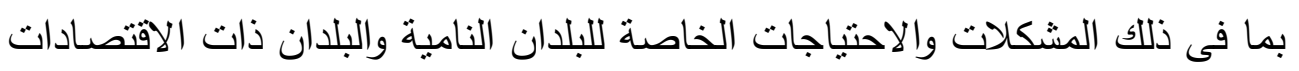
الانتقالية.

وإنشـاء آليات طوعيـة بهدف المسـاهمة ماليـا فى الجهود التـى تبذلها البلدان

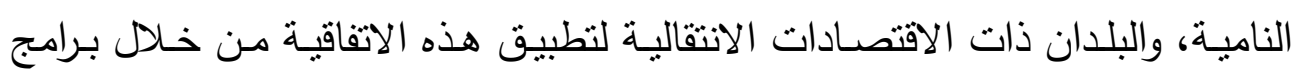
ومشاريع المساعدة التقنية.

وتقديم تبرعات إلى مكتب الأمم المتحدة المعنى بالمخدرات والجريمـة بغرض لئل

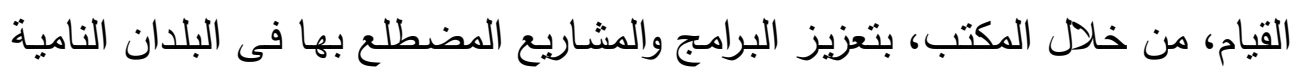
بهدف تتفيذ هذه الاتفاقية( المادة م ـ). وفى مصـر ، أنثـأ المشـرع الأكاديميـة الوطنيـة لمكافحـة الفسـاد بهيئة الرقابـة

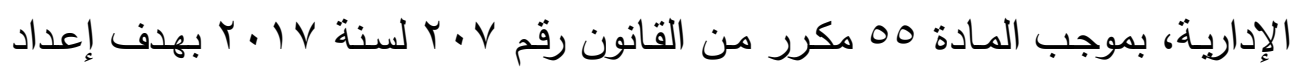

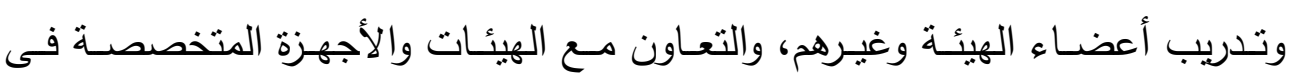

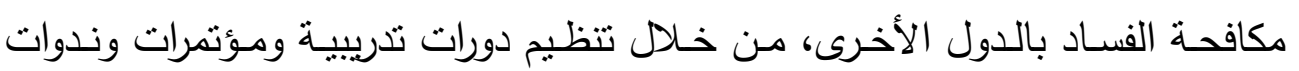

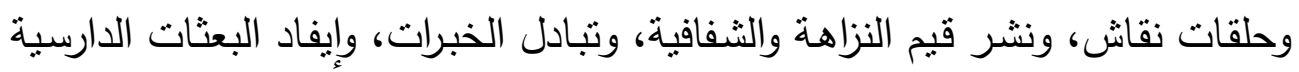

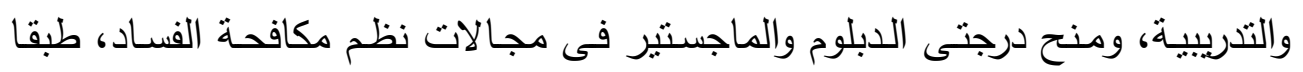


للأوضـاع المقررة قانونـا، وذلك بالتتسيق مـع المجلس الأعلى للجامعات، لاعتمـاد الدرجات العلمية الممنوحة.

\section{ثالثا: التمديات المرتبطة بتتبع عائدات الفساد وهصادرتها}

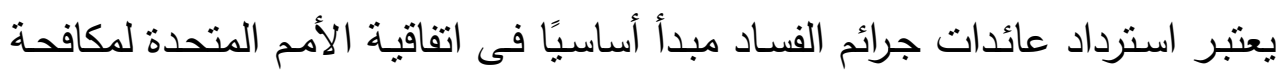

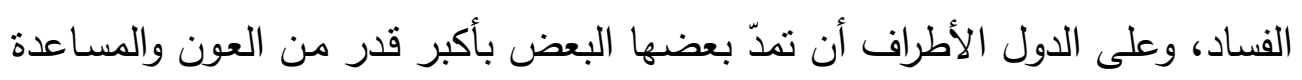
فى هذا المجال (المادة (0).

ويجب أن تكون لدى الدول قوانين وإجراءات فعالة لتجميد أو مصادرة عائدات

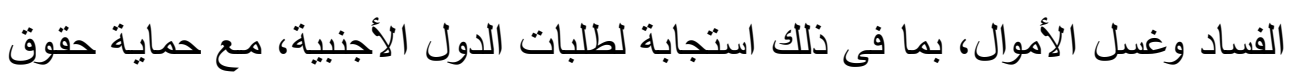

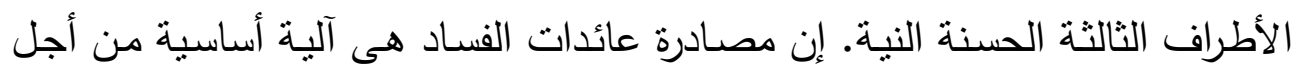
حرمان المسئولين الفاسدين والأفراد من مكاسبهم غير المشروعة. يمكن للدول إزالة الحافز على الانخراط فى أنشطة فاسدة عن طريق حرمان الجناة وغيرهم من الاستفادة

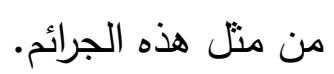

ويوجد لدى العديد من الدول بالفعل إطار قانونى كافٍ للتمكين من المصادرة،

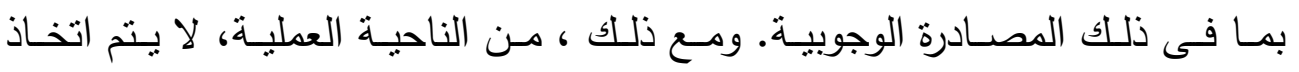

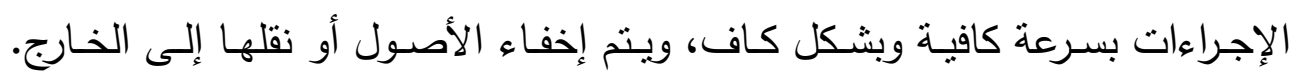

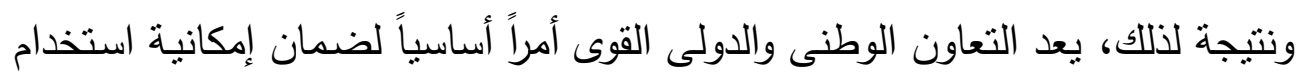
وسائل الاستخبارات المالية التى يتم جمعها من خلال تدابير مكافحة غسل التهل الأموال

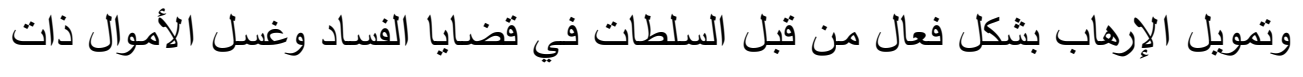

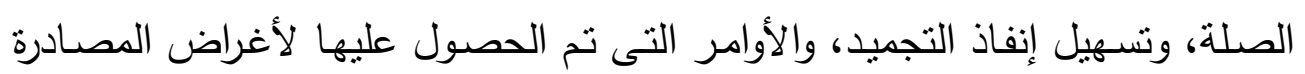
فى نهاية المطاف، وكذللك الأحكام النهائية المصادرة.(•). 
وتتطلب اتفاقية الأمم المتحدة لمكافحة الفساد من الدول الأطراف، وإلى أقصى

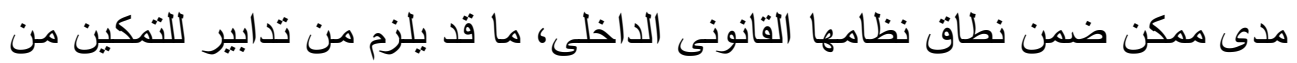

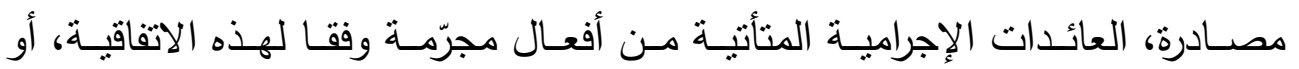

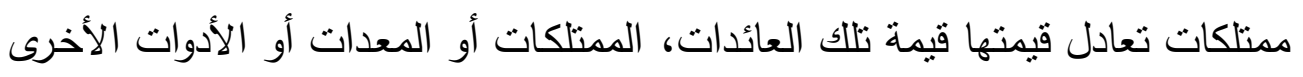
التى استخدمت أو كانت معدة للاستخدام فى ارتكاب أفعال مجرمة وفقا لهذه الاتفاقية.

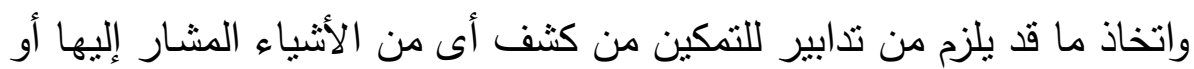
اقتفاء أثنره أو تجميده أو حجزه، لغرض مصادرته فى نهاية المطاف.

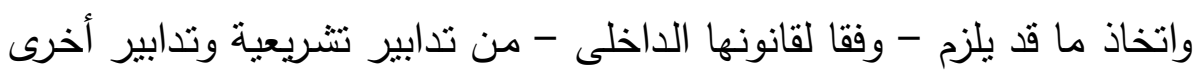
لتتظيم إدارة السلطات المختصة للممتلكات المجمدة أو المحجوزة أو المصادرة. ولا يجوز تأويل أحكام هذه المـادة بما يمس بحقوق الغير حسن النية (المـادة

وفى ضوء ما تقدم نسلط الضوء على بعض الآليات الضرورية لتتبع عائدات

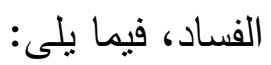

\section{ا - التوازن بين هبدأ سرية الصسابات البنكية، وتتبع عائدات جرائم الفساد}

تعد قاعدة السرية البنكية - والتى تلتزم البنوك بأن تحافظ على سـرية المعلومـات

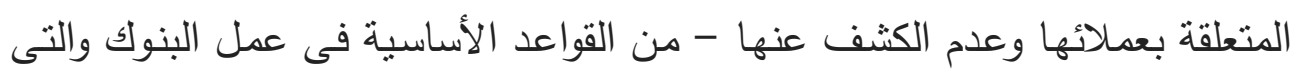
تحظى بحماية القانون. غير أن هذه السرية قد تعوق إجراءات تتبع واسترداد الأموال المتحصلة من جرائم، لذا عكفت الاتفاقيات الدولية على التخفيف من وطأة هذا المبدأ.

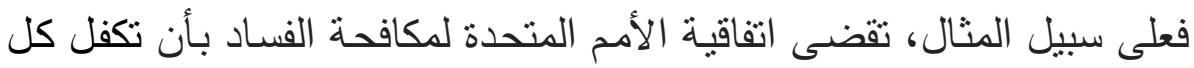

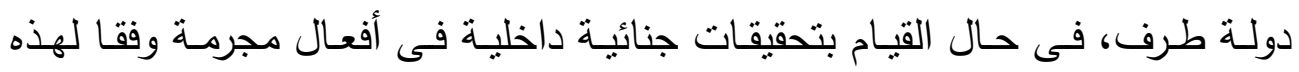


الاتفاقية، وجود آليات مناسبة فى نظامها القانونى الداخلى لتنليل العقبات التى قد

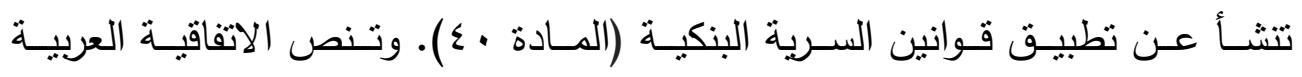

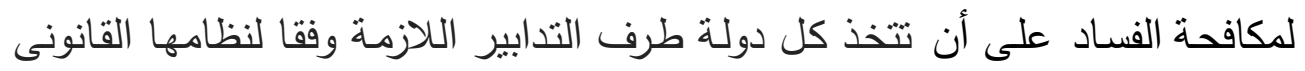

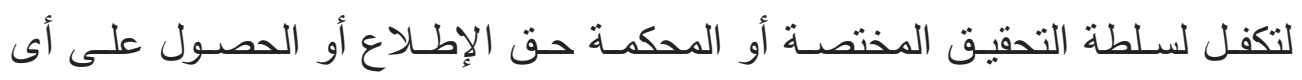

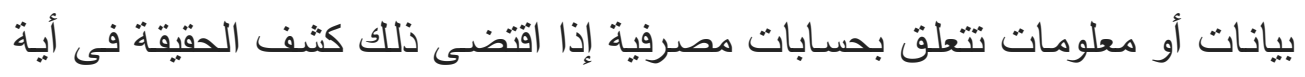

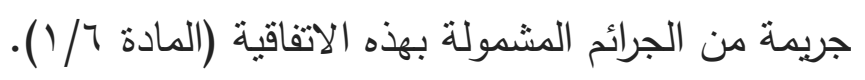

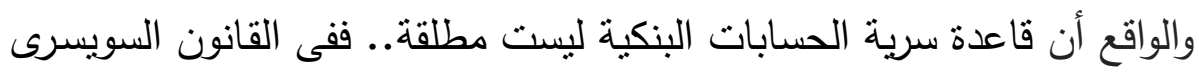

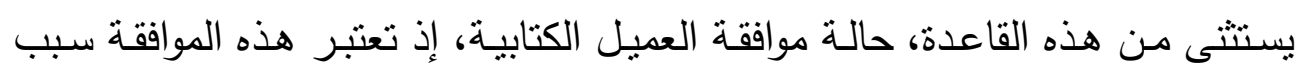

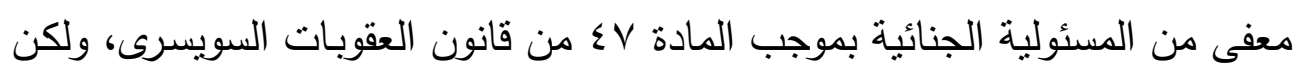

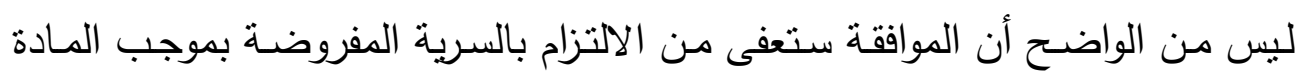

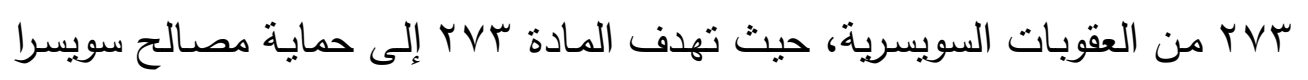

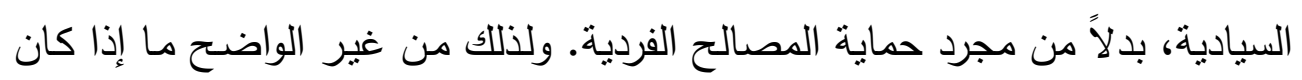

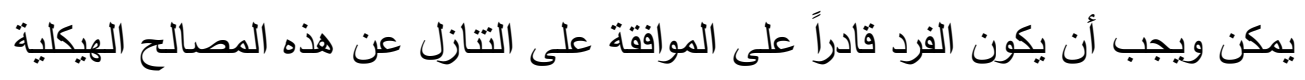
وكذلك مصالحه الفردية.

والحالة الثانية فى حالة صدور أمر من السلطات السوسرية المختصة في سياق

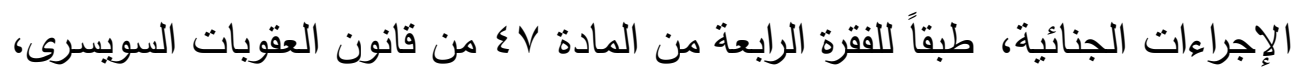

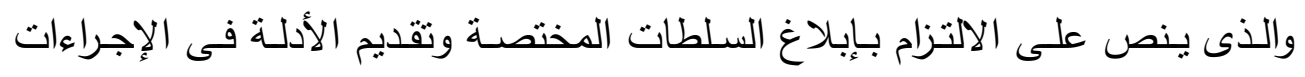
الجنائية. ففى هذه الإجراءات، لا تتطبق قاعدة السرية المصرفية("rابل. 


\section{أ- هوقف القانون المصرى}

القاعدة فى القانون المصرى هـ سرية الحسـابات البنكية، وفى ذلك نص قانون

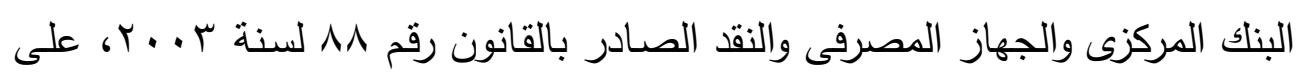

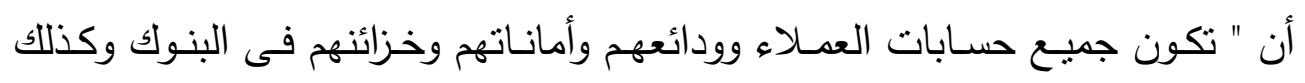

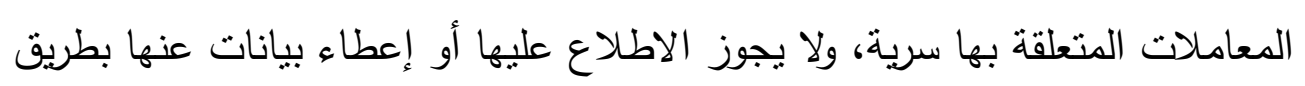

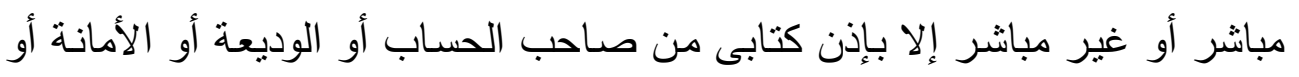

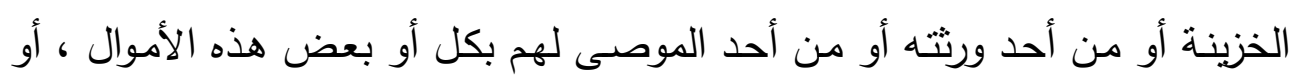

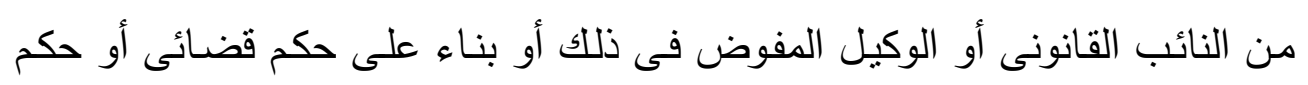
محكمين.

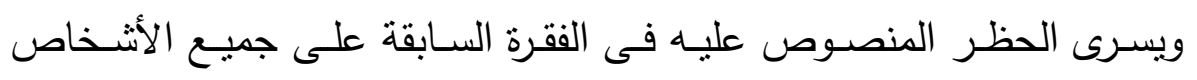

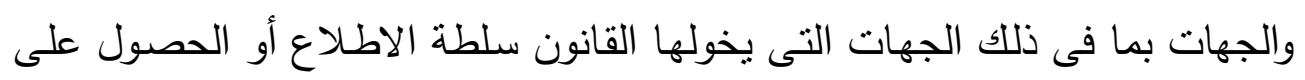

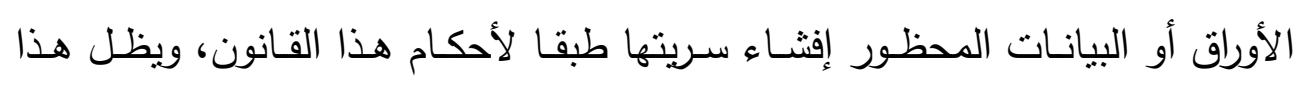

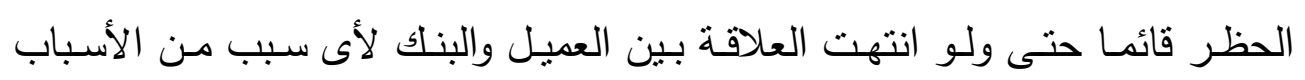

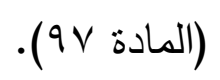

\section{ب- الاستثناء هن سرية المسابات البنكية}

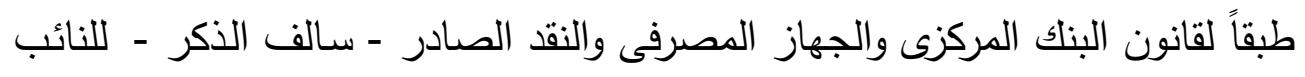

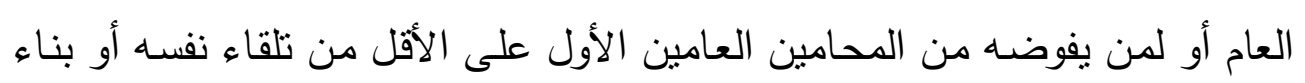

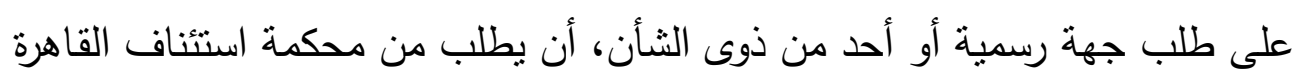

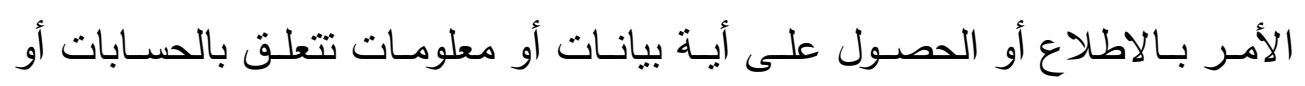

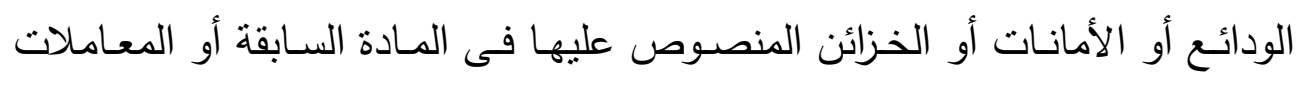


المتعلقة بها إذا اقتضى ذللك كثف الحقيقة فى جناية أو جنحة قامت الدلائل الجدية على وقوعها. ولأى من ذوى الثنأن فى حالة التقرير بما فى الذمة بمناسبة حجز موقع لدى

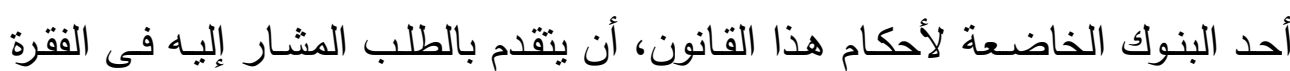
السابقة إلى محكمة الاستئناف المختصة. وتقصل المحكمة منعقدة فى غرفة المشورة فى الطلب خلال الأيام الثلاثة التالية لتقديمه بعد سماع أقوال النيابة العامة أو ذى الثنأن.

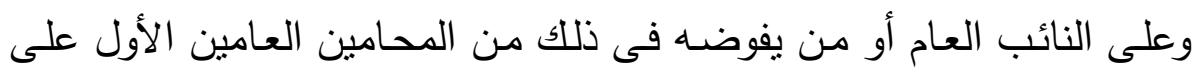

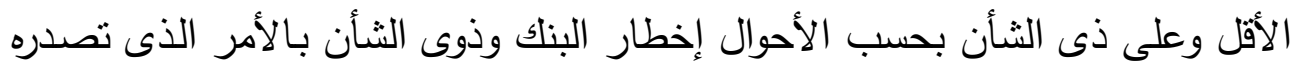
المحكمة خلال الأيام الثناثة التالية لصدوره. ويبدأ سريان الميعاد المحدد للتقرير بما فى الذمة من تاريخ إخطار البنك بالأمر

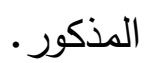

ويكون للنائب العام أو من يفوضهه من المحامين العامين الأول على الأقل أن

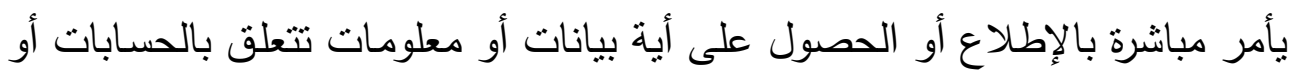

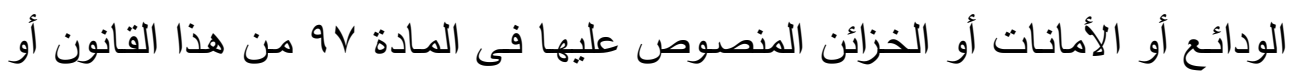

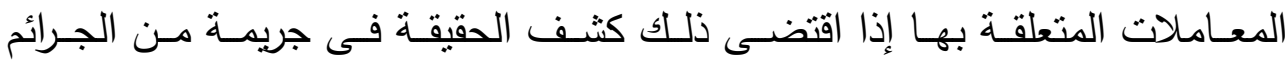
المنصوص عليها فى القسم الأول من الباب الثانى من الكتاب الثانى مـ قانون

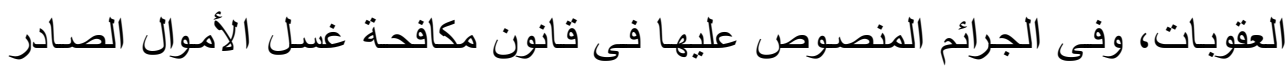

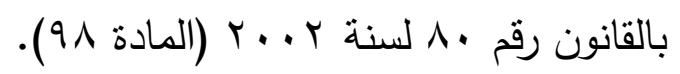




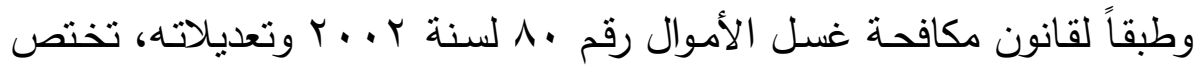
وحدة مكافحة غسل الأموال وتمويل الإرهاب بتلقى الإخطارات الواردة من المؤسسات الأسوال

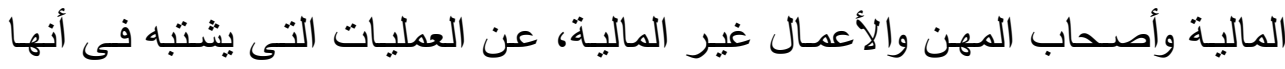

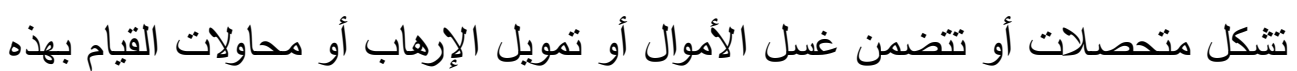

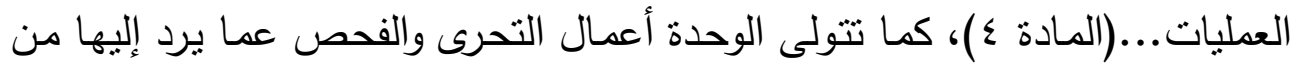

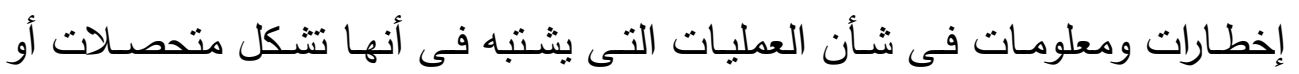

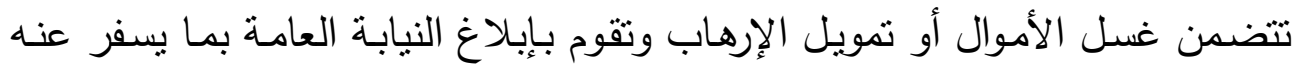

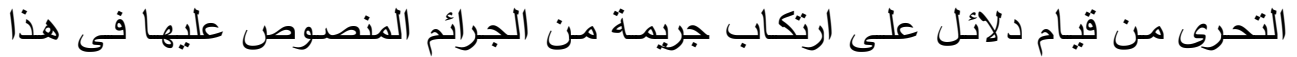
القانون...وتنرى على جرائم غسل الأموال وجرائم الإرهاب وجريمة تمويل الإرهاب

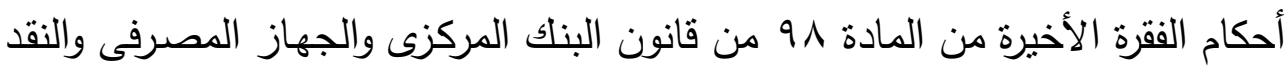
والمشار إليها آنفاً (المادة 0).

\section{r- r التمفظ على أهوال المتهم}

غالباً ما نستغرق إجراءات التحقيق فى قضايا الفساد وقتاً طويلاً، لصعوبة التحقيق

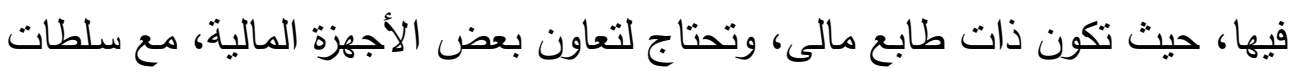

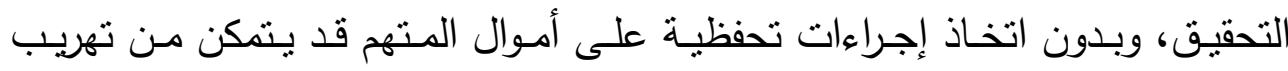

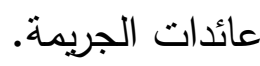

ولهذا اتجهت السياسة الجنائية المعاصرة إلى جواز اتخاذ تدابير تحفظية على

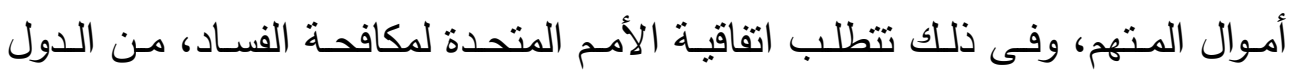
الأطراف اتخاذ ما قد يلزم من تدابير للتمكين من كثف أى من العائدات الإجرامية

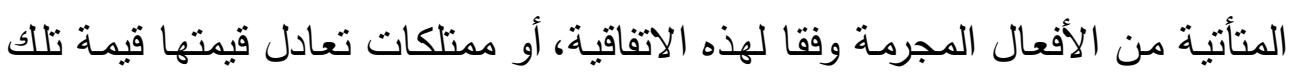


العائدات، والممتلكات أو المعدات أو الأدوات الأخرى التى استخدمت أو كانت معدة

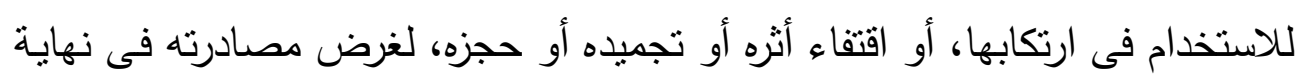

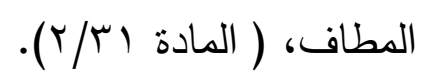
ويعطى قانون مكافحـة غسل الأموال، لوحدة غسل الأموال وتمويل الإرهاب بالبنك المركزى، الحق فى أن تطلب من سلطات التحقيق اتخاذ التدابير التحفظية الإنة

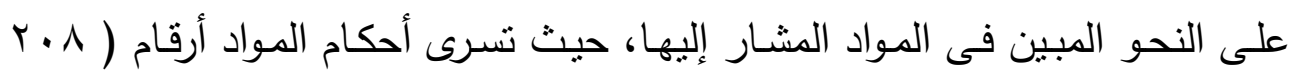

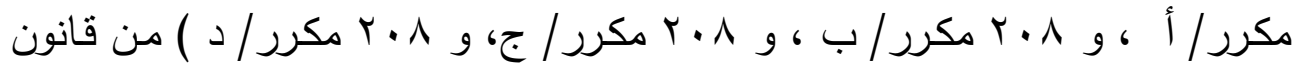

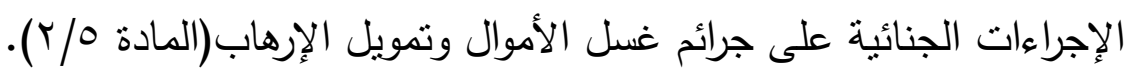

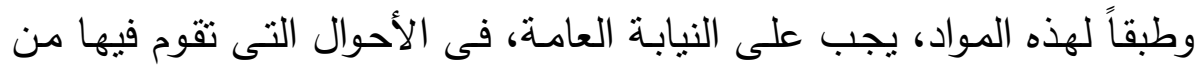

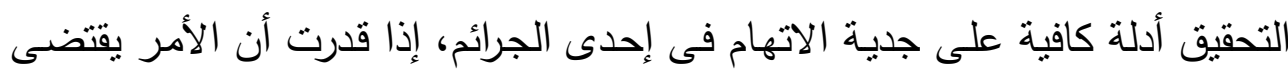

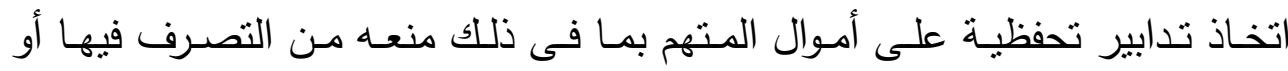

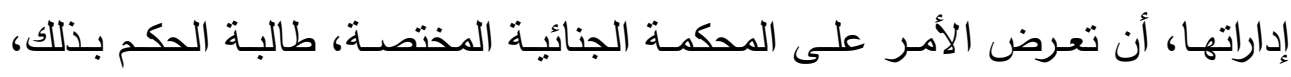

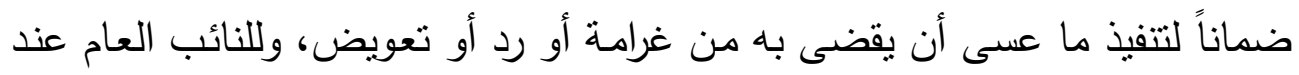
الضرورة أو فى حالة الاستعجال أن يأمر مؤقتاً بمنع المتهم أو زوجه أو أو أو أولاده القصر من التصرف في أموالهم.

ويترتب على هذا الإجـراء حرمـانهم مـن حـق التصـرف فـى أمسالهم العقاريـة

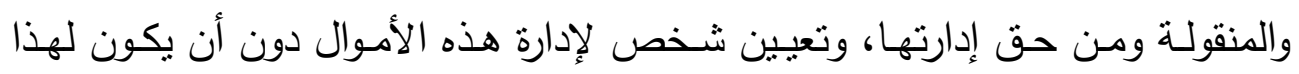

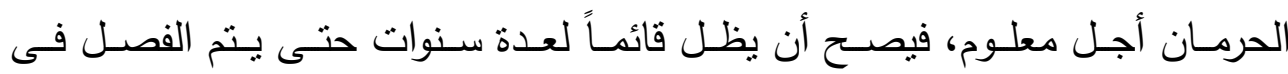

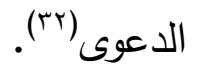


كما يعطى قانون الكسب غير المشروع، هيئات الفحص بإدارة الكسب غير

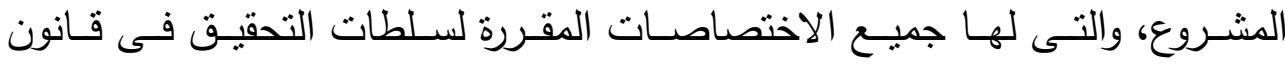

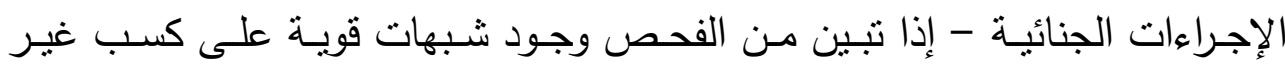

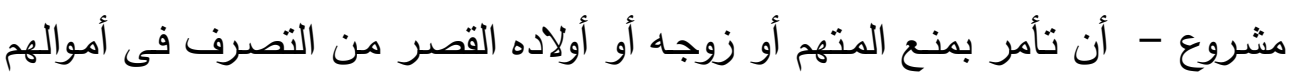

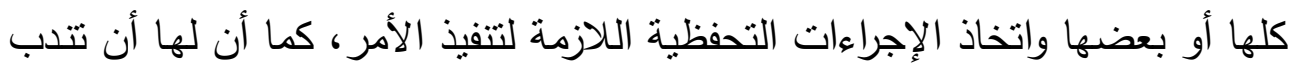
النيابة العامة لتحقيق وقائع معينة.

على أن يشتمل أمر المنع من التصرف معنة على تعيين من يدير الأموال المتحفظ

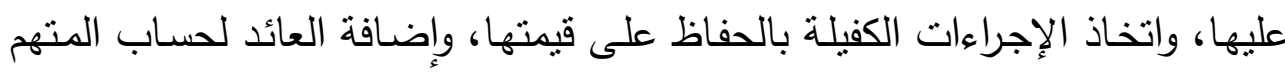

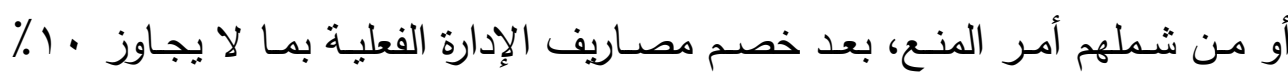

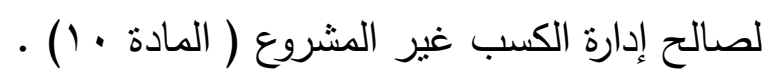

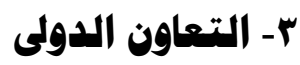

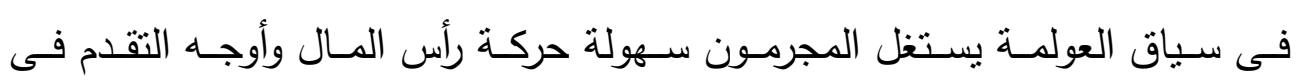

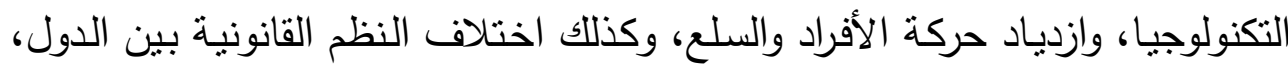

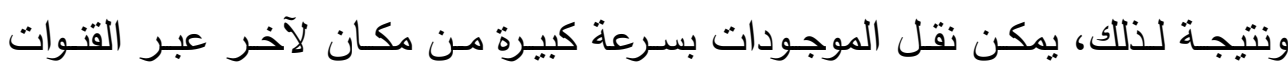

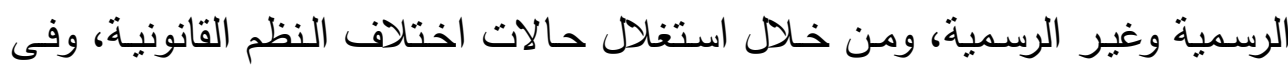
النهاية قد تظهر الأموال فى شكل مشروع فى أى منطقة من مناطق العالم(rr).

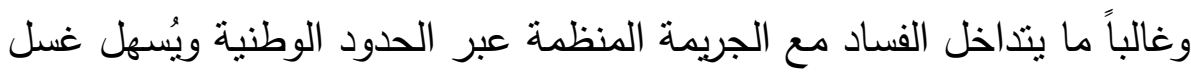

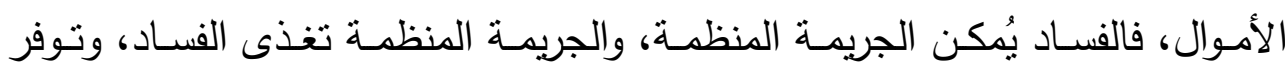

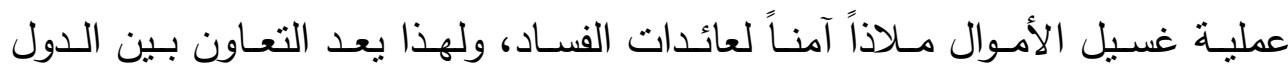

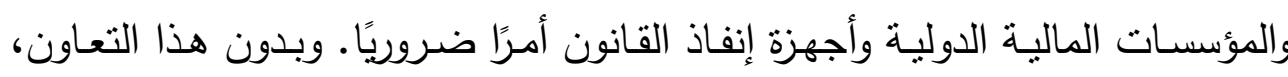


سيتم إخفاء عائدات الفساد والجريمة المنظمة فى الخارج. وعلى الرغم من ذلك لا يزال

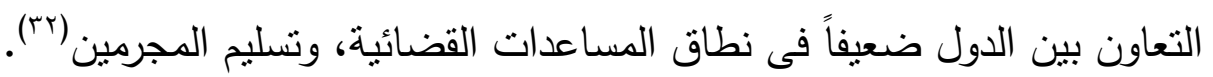

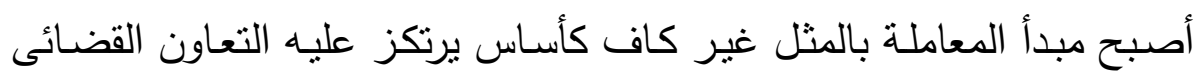

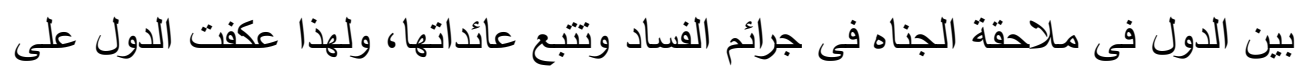

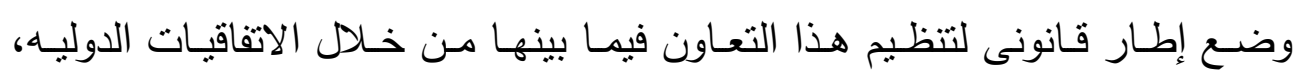
والقوانين الوطنية.

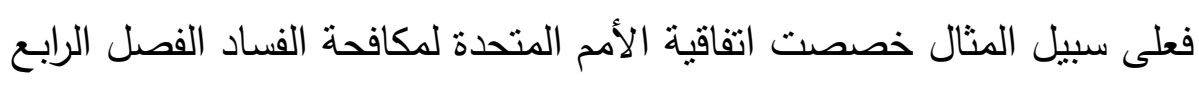

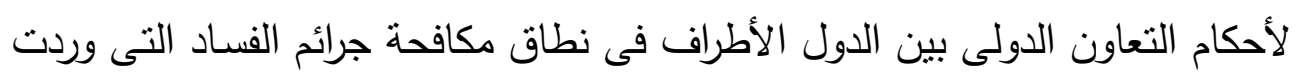

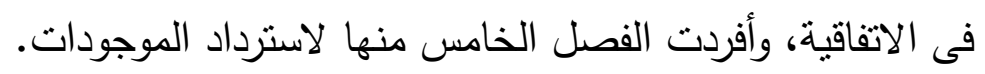
وعلى مستوى القوانين الوطنية، ينص قانون غسل الأموال على أن، تتبادل

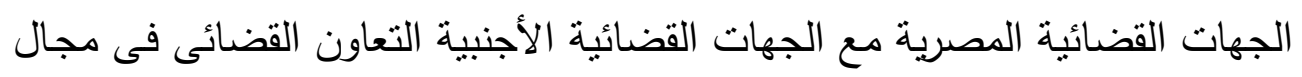

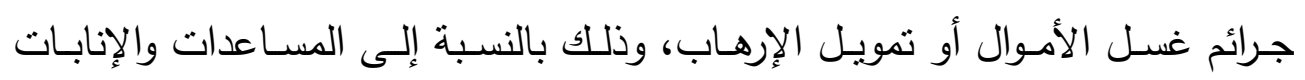

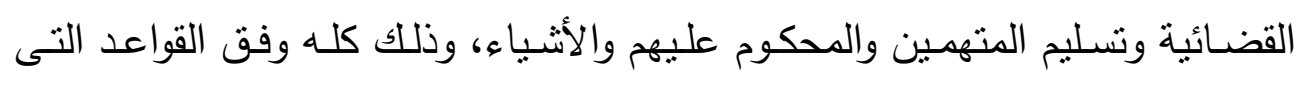

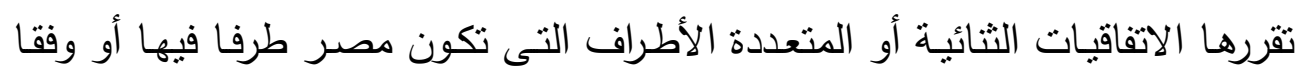

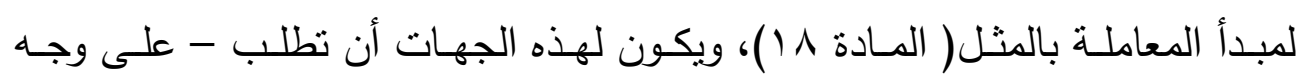

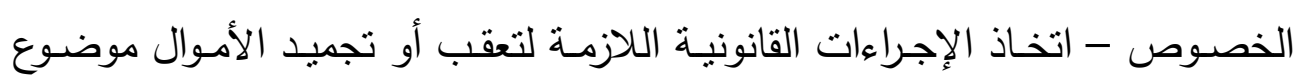

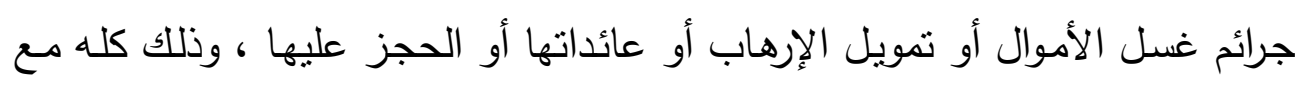
عدم الإخلال بحقوق الغير حسن النية( المادة 9 (1).

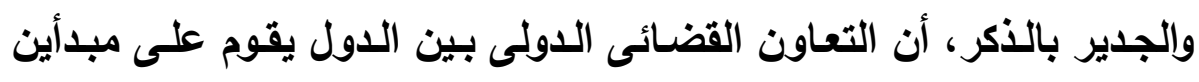


المبـدأ الأول: مبـدأ ازدواج التجريم، والذى يتطلب أن يكون الفعل المرتكب

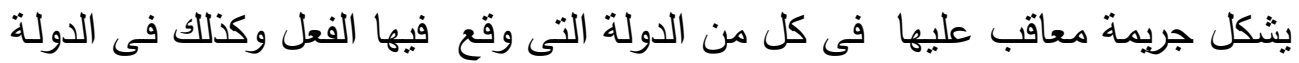
التى ينم فيها اتخاذ الإجراءات الجنائية. المبدأ الثانى: مبدأ عدم العقاب عن الفعل الواحد مرتين، ويعد هذا المبدأ أحد

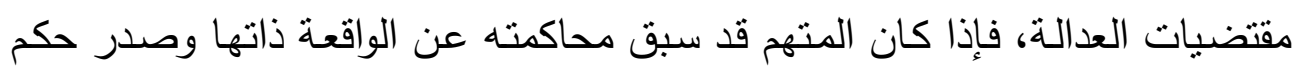
بات ببراءته أو أدين ونفذ العقوبة لا تجوز محاكمته مرة ثانية.

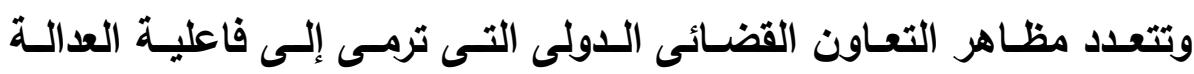

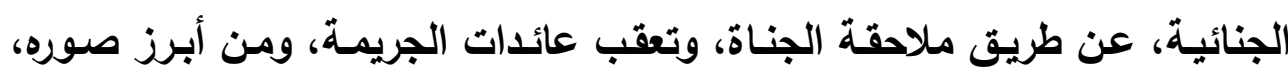

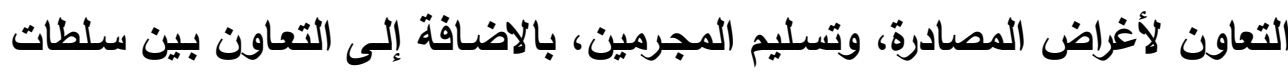
الضبط القضائى. وقد تضمنت اتفاقية الأمم المتحدة لمكافحة الفساد، آليات استزداد الممتلكات من خـلال التعاون فى مجال المصـادرة، ومن بين الالتزامات التى تقع على الدول

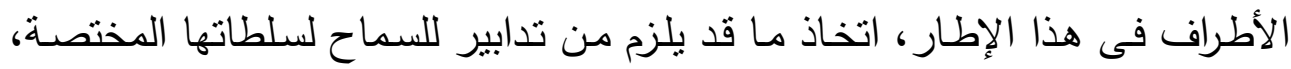

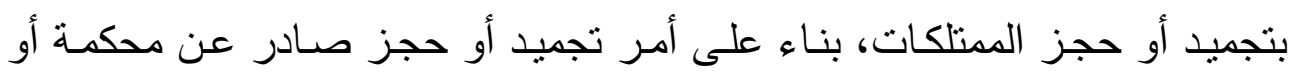

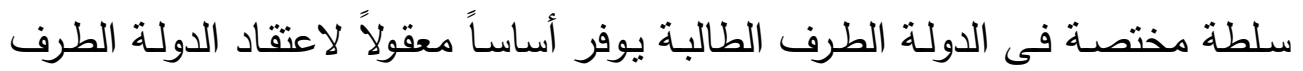

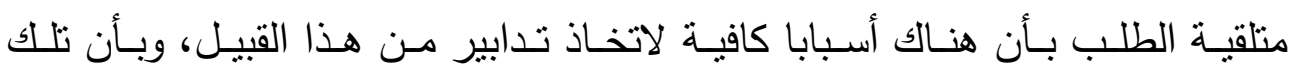
الممتلكات ستخضع فى نهاية المطاف لأمر المصادرة.

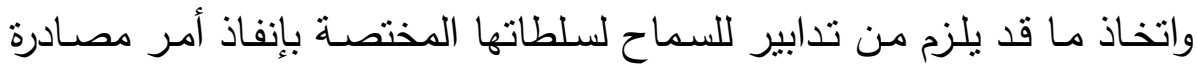
صادر عن محكمة فى دولة طرف أخرى. 
والسـماح لسـلطاتها المختصـة، عندما تكـون لديها ولايـة قضـائية، بـأن تـأمر

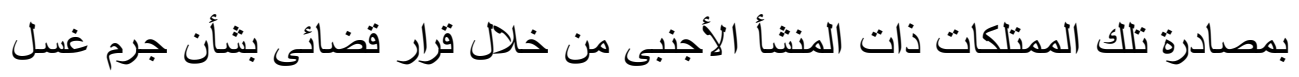

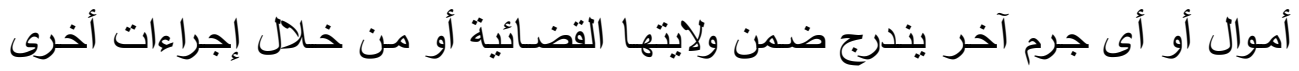

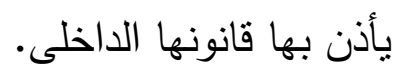
وأيضاً النظر فى اتخاذ ما قد يلزم من تدابير للسماح بمصادرة تلك الممتلكات

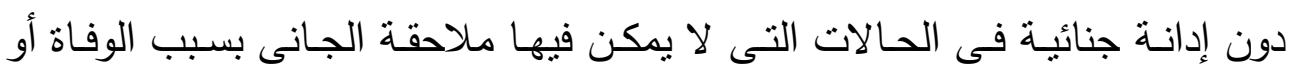
الفرار أو الغياب أو فى حالات أخرى مناسبة (المادة ؟ ه).

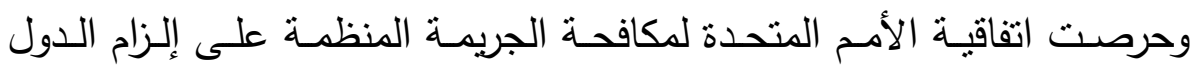

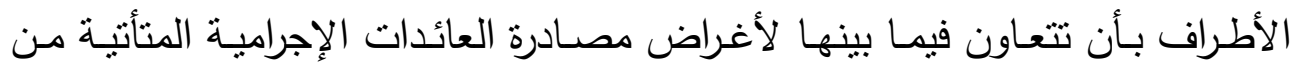

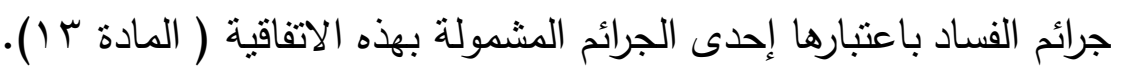

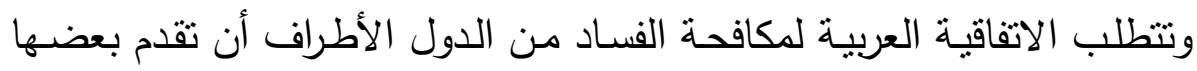
إلى بعض أكبر قدر ممكن من المساعدة القانونية المتبادلة فى التحقيقات والملاحقات

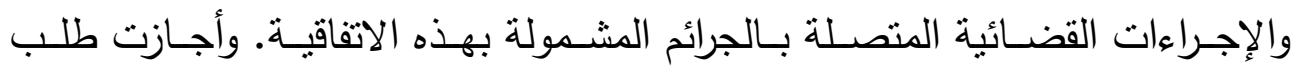

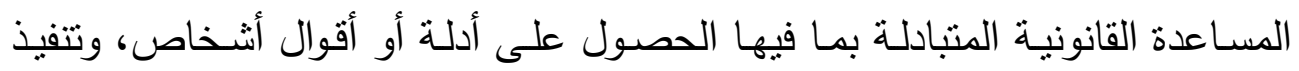

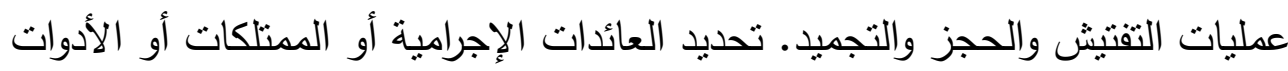
أو الأشياء الأخرى أو اقتفاء أثرها لأغراض إثباتية. استرداد الممتلكات (المادة • ب).

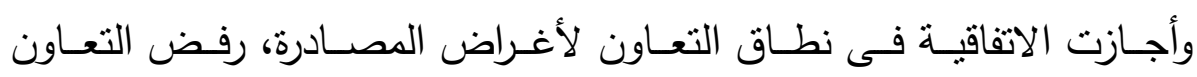

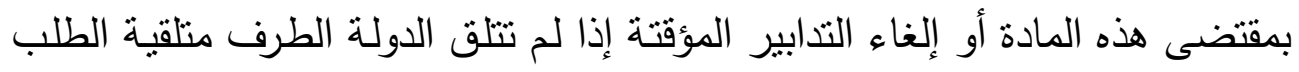

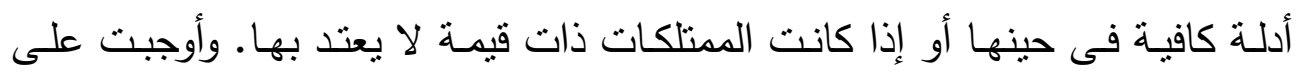
الدولة متلقية الطلب - قبل وقف أى تدبير مؤقت اتخذ عملاً بهذه المادة - أن تتيح 
للدولة الطرف الطالبة، حيثما أمكن ذلك، فرصة لعرض ما لديها من أسباب تستدعى

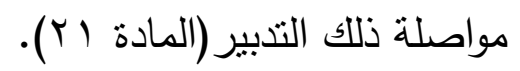
و هناك بعض المعوقات التى تعوق التعاون القضائى بين الدول فى نطاق جرائم

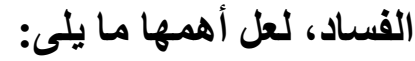
1 - اختلاف النظم القانونية والإجرائية بين الدول: حيث يشكل هذا الاختلاف أحد أهم المعوقات التى تعوق التعاون القضائى الدولى فى نطاق جرائم الفساد، خاصة

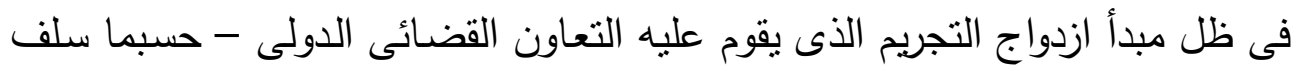

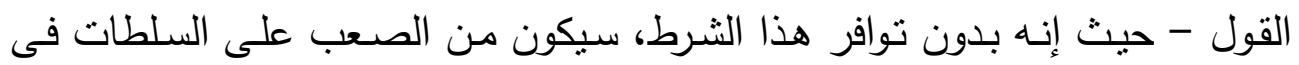

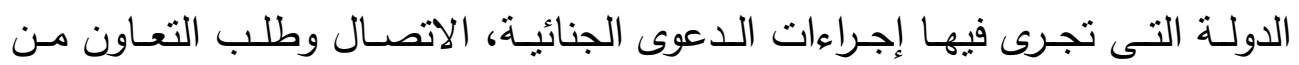
سلطات الدولة التى وقع فيها الفعل.

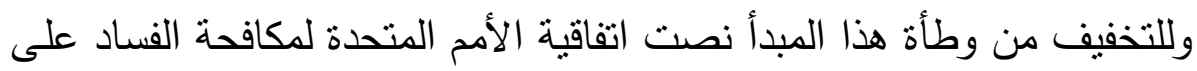

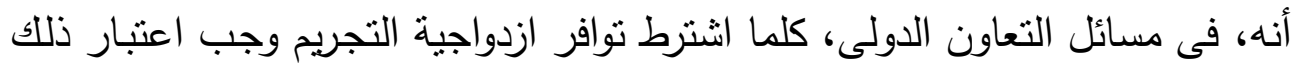
الثرط مستوفيًا بصرف النظر عما إذا كانت قوانين الدولة الطرف متلقية الطلب تدرج

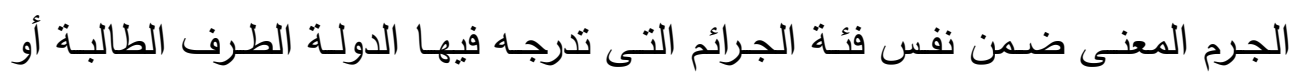

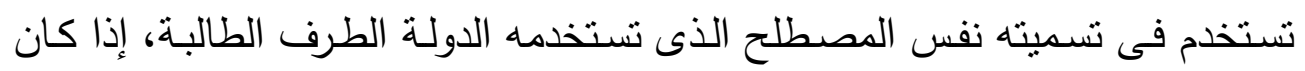

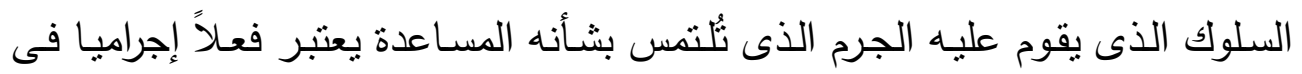

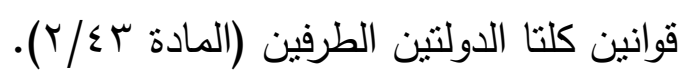
Y- إحدى السمات الرئيسية للتعاون بين الدول يتمثل في بطع بـ الإجراءات: حيث يجرى هذا التعاون فى إطار إجراءات معقدة تأخذ وقتاً طويلاً من الزمن. 
ب- بظل التعاون القضائى الدولى مقيداً باحترام النظام العام الاخلى للاولة،

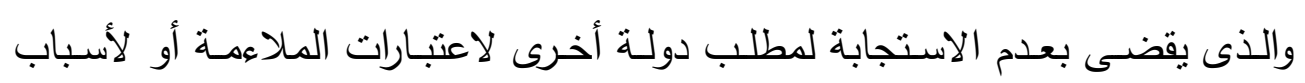
سباسية(r)

؛ - إذا كان مبدأ عدم جواز تسليم رعايا الدول، يمثل تأكيداً لسيادة الدولة

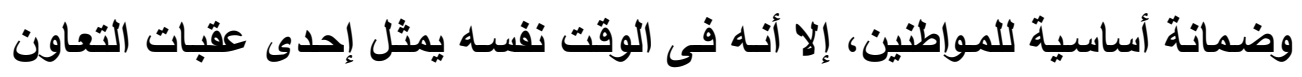
القضائى الدولى فى مكافحة جرائم الاتجار بالبشر العابرة للحدود الوطنية.

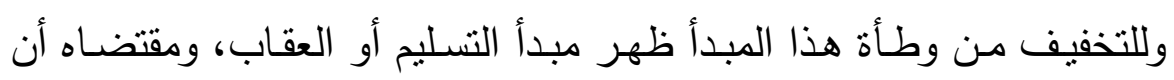

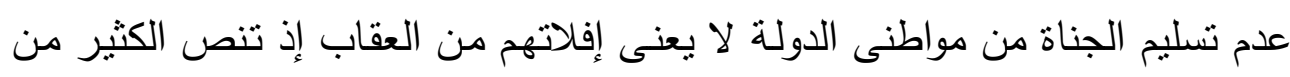

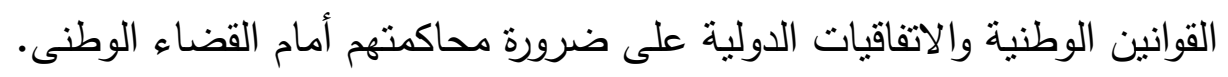

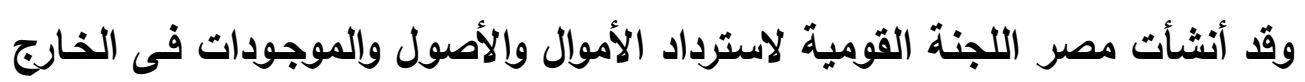

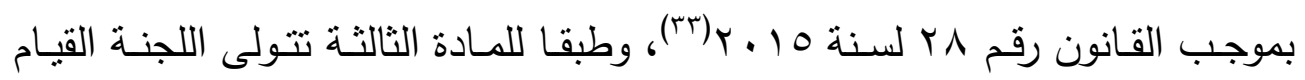

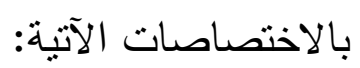
1- تمثيل الدولة أمام الجهات المعنية بالدول والمنظمات الدولية فى نطاق استرداد

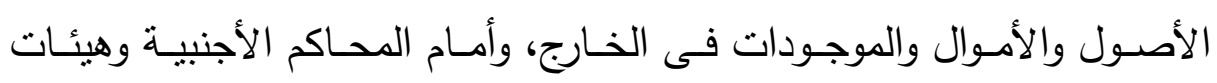

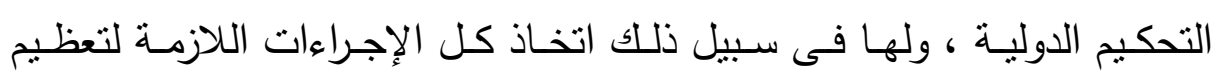

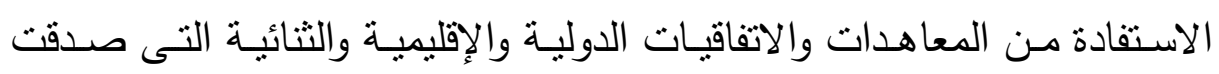
عليها مصر ذات الصلة بهذا الثأن. r- وضع استراتيجية قومية لاسترداد الأصول والأموال المهربة فى الخارج، وآليات لتنفيذ هذه الاستراتيجية، ومتابعة تتفيذها. 
r- اتخاذ ما يلزم من إجراءات قانونية وإدارية وتقديم الطلبات باسم الدولة المصرية

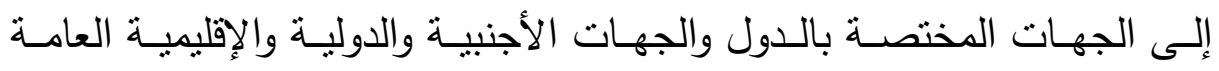

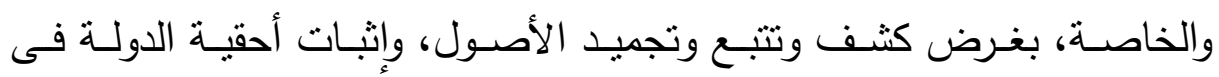
استردادها، والعمل على متابعة ما ينم بشأنها. ع - تبادل التحريات الجنائية والمالية، والمعلومات القضائية هائية مع الجهات التهات المعنية بالدول

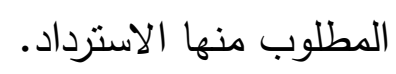

ه- طلب المعلومات والإيضاحات من جميع الجهات المعنية بشأن المتهمين والجرائم محل طلبات الاسترداد.

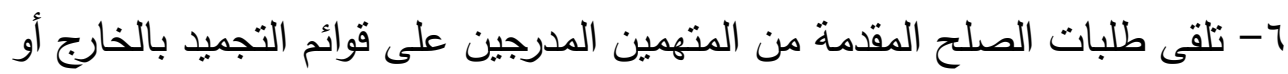
وكلائهم الخاصين فى أية مرحلة كانت عليها الدعوى الجنائية.

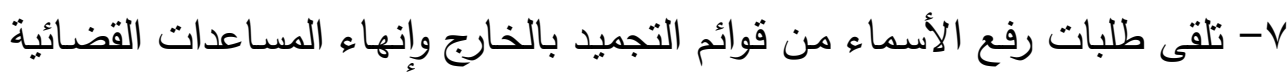

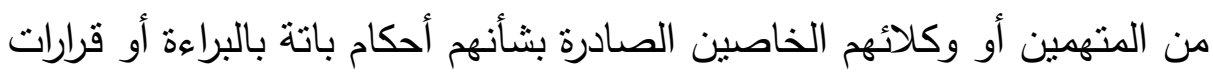

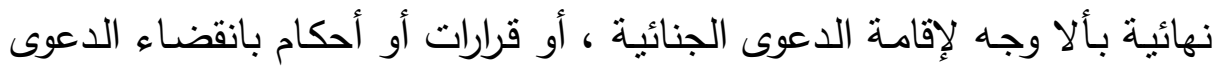

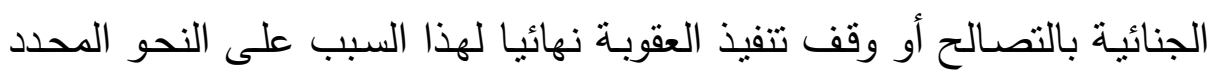

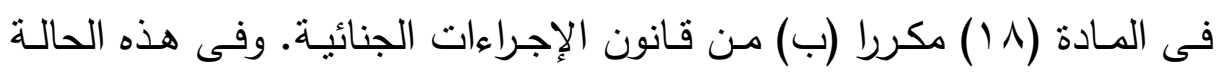

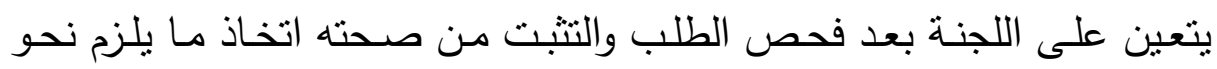
مخاطبة الدولـة الأجنبيـة لرفع تلك الأسماء وإنهاء طلبـات المسـاعدة القضـائية بشأنه. ^- اتخاذ ما يلزم من إجراءات مع الدول الأجنبية فى شأن استرداد الأموال والأصول فى ضوء ما تتطلبه قوانين تلك الدول والقواعد المعمول بها لديها فى هذا الثنأن. 
وتتولى اللجنة دون غيرها نلقى طلبات الصلح المقدمة من المتهمين المدرجين

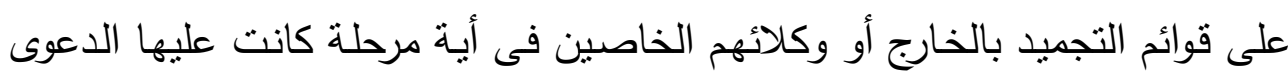

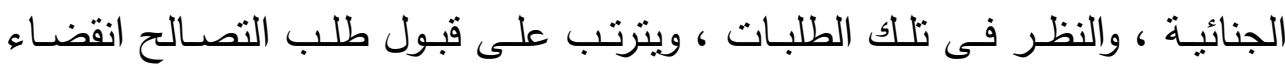
الدعوى الجنائية أو وقف نتفيذ العقوبـات المحكوم بها بحسب الأحوال عن الجرائم محل الطلب على النحو المحدد فى المـادة 11 مكررا (ب) من قانون الإجراءات الجنائية (للمادة7).

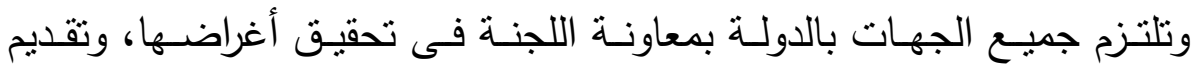

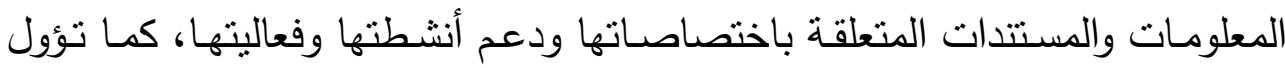
للجنة كل وثائق ومستتدات وموجودات اللجنة المشكلة بقرار رئيس المجلس الأعلى

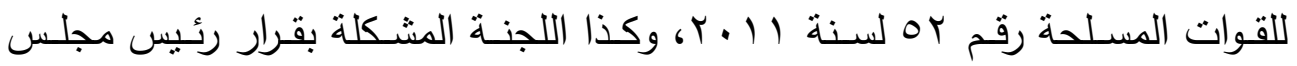

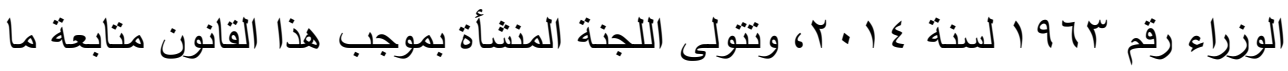

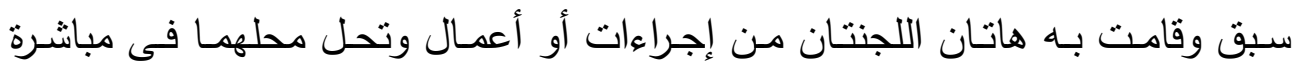
اختصاصاتهما على النحو المبين بهذا القانون(المادة 9) . 


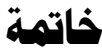

يتضـح مهـا تقدم، أنـه إزاء صعوبة الكثف عن جرائم الفساد وتتبع عائداتها، يتعين تعبئة كل الجهود لمكافحة آفة الفساد، ونعتقد أن التحدى الأكبر يبدأ بفهم تصورات المواطنين حول الفساد، وهناك حاجة مستمرة لتوعيتهم بمخاطر الفساد، ويمكن تحقيق الوعى العام عن طريق مشاركتهم فى مكافحة الفساد، الأمر الذى يؤدى إلى خلق بئئنة

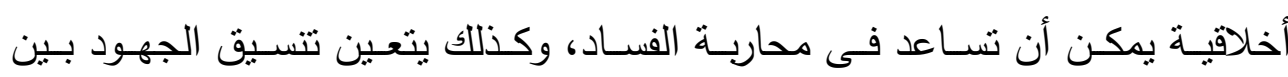

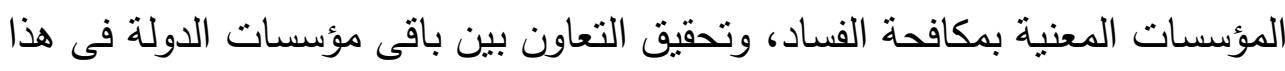

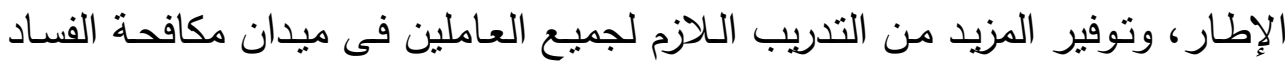

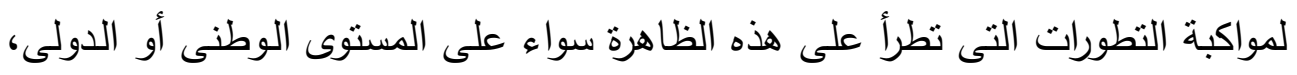

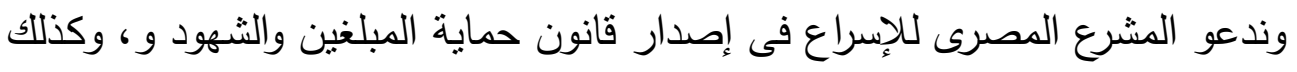

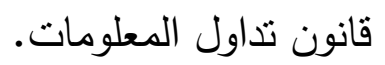




\section{المراجع}

1- وافقت مصر على الاتفاقية الدولية للحقوق المدنية والسياسية (العهد الدولى) بموجب قرار

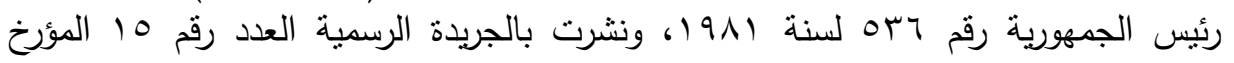
$.191 \mathrm{r} / \leqslant / 10$

r- وفقًا لتقرير الأمانة العامة للأمم المتحدة المقدم لمؤتمر الدول الأطراف فى اتفاقية الأمم المتحدة

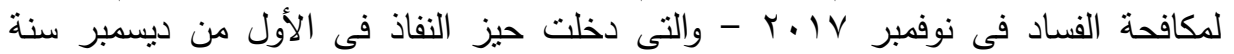

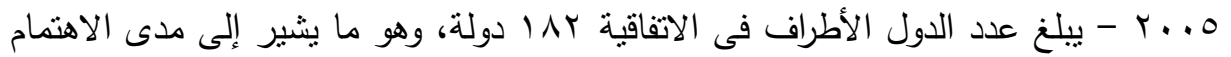

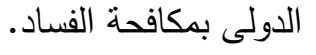

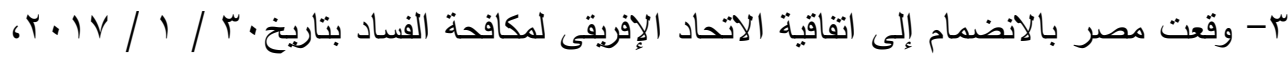

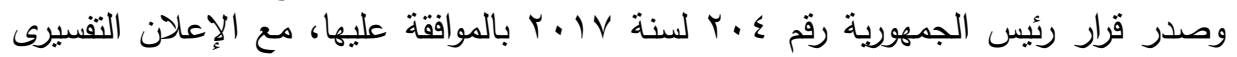

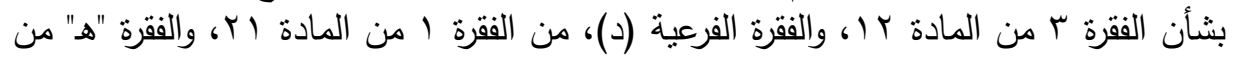

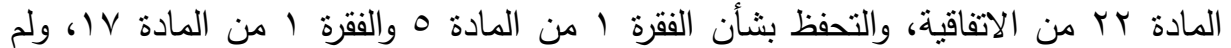

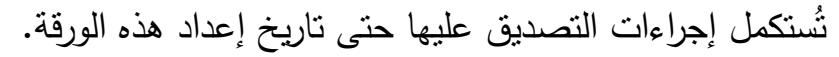

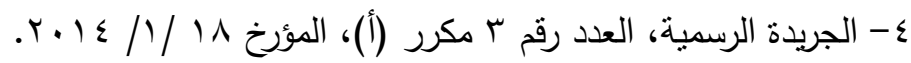

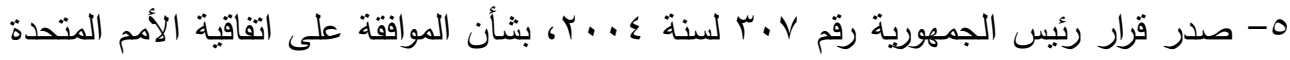

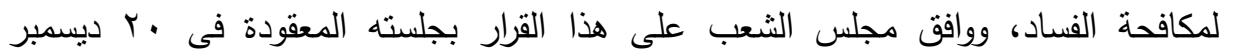

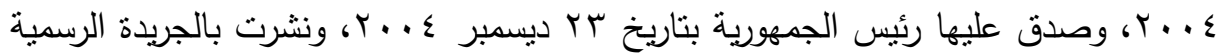

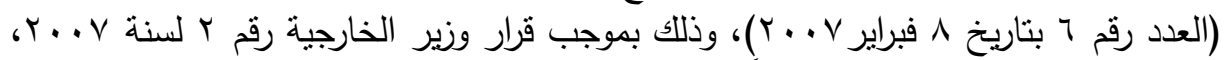

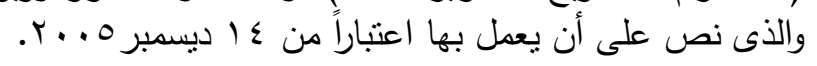

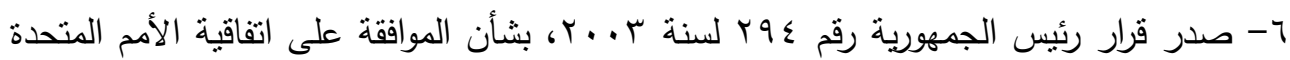

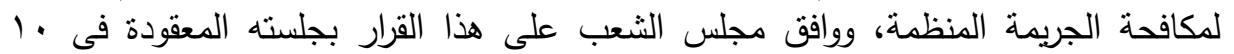

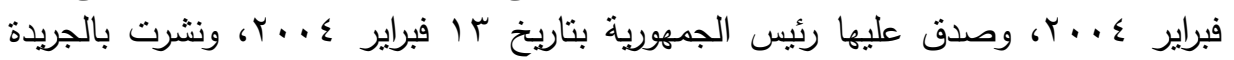

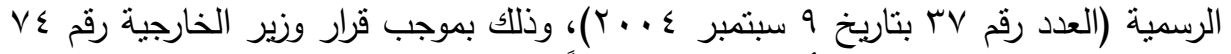

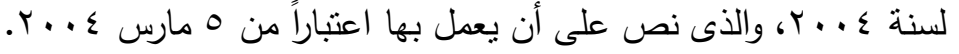

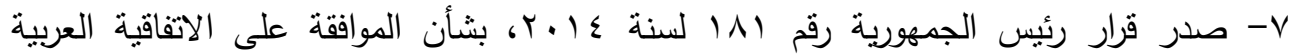

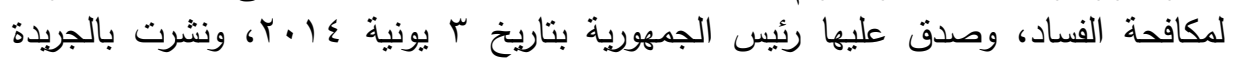




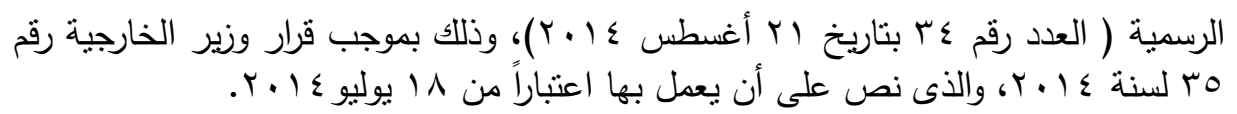

8- Johann Graf Lambsdorff, The Institutional Economics of Corruption and Reform:

Theory, Evidence, and Policy, Cambridge University Press, 2007, p. 241.

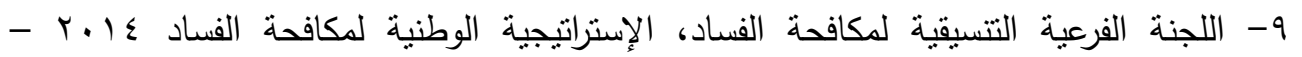
(1)

• 1- مكتب الأمم المتحدة المعنى بالمخدرات والجريمة، الدليل التشريعى لتنفيذ اتفاقية الأمم المتحدة

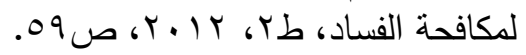

1 ا إبراهيم سلامة، الجرائم ضد الإنسانية، فصل فى مؤلف المحكمة الجنائية الدولية، الموائمة

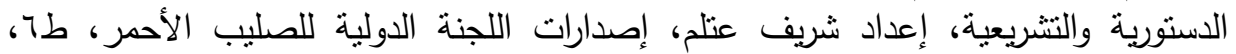

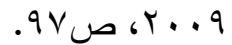

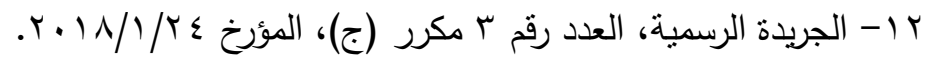

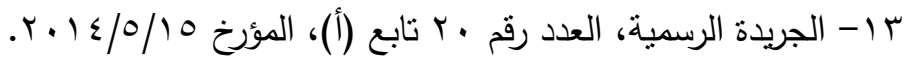

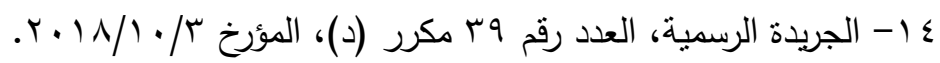

15- Frederic Lemieux, Garth den Heyer, Dilip K. Das: Economic Development, Crime, and Policing Global Perspectives,CRC Press, 2015, p. 220.

16- Transparency International: People and Corruption: Voices of Citizens from Around the World, Global Corruption Scale, 2017, p. 10.

17- Frederic Lemieux, Garth den Heyer, Dilip K. Das: Op.cit, p. 208.

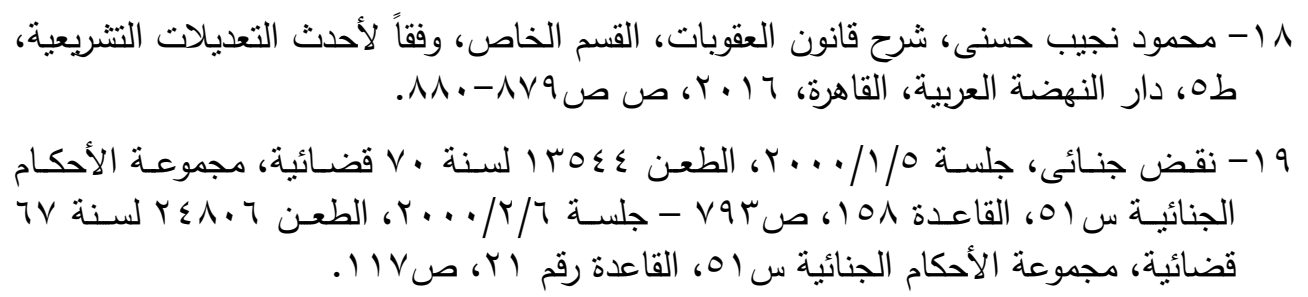

20- CNCDH: Avis sur le projet de loi relatif à la transparence, à la lutte contre la corruption et à la modernisation de la vie économique. Paris, 2016, pp. 22-23. 


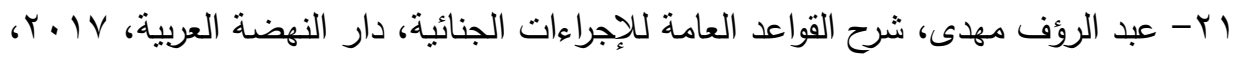

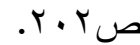

$$
\begin{aligned}
& \text { r r - محمود نجيب حسنى، شرح قانون العقوبات، القسم العام، النظرية العامة للجريمة والنظرية }
\end{aligned}
$$

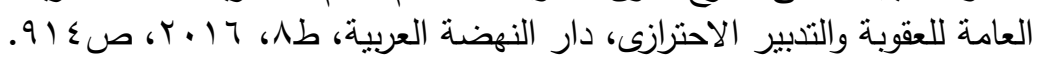

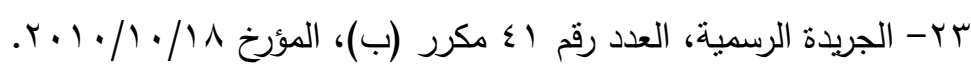

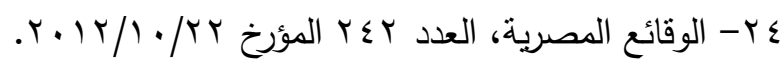

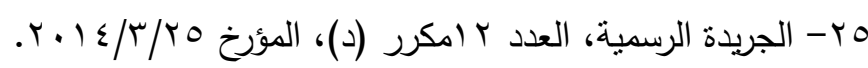

جr- وافقت مصر على اتفاقية إنثاء الأكاديمية الدولية لمكافحة الفساد بصفتها منظمة دولية،

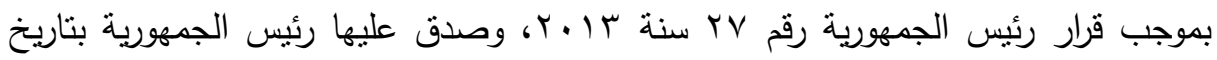

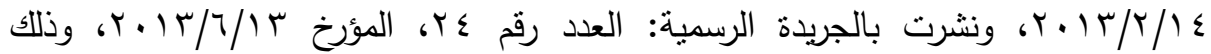

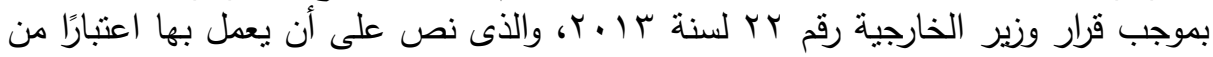

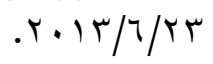

27- FATF: Best practices, using the recommendations of the TATF against Corruption, Paris, 2013, p.12.

28- Ndiva Kofele-Kale, Combating Economic Crimes, Balancing Competing Rights and Interests in Prosecuting the Crime of Illicit Enrichment, Routledge, 2012, pp. 301-302.

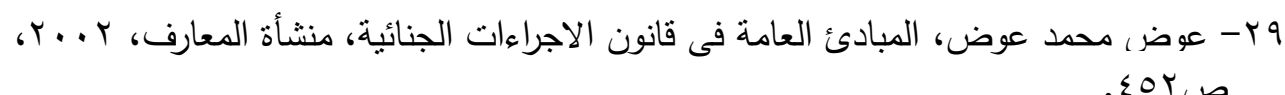

$$
\text { . ץ- مكتب الأمم المتحدة المعنى بالمخدرات والجريمة، المرجع السابق، ص979. }
$$

31- Kaushik Basu and Tito Cordella, Institutions, Governance and the Control of Corruption, Palgrave Macmillan. 2018, p.p 99 -101.

r T- محمود محمود مصطفى، موضوعات المؤتمر الثالث عشر لقانون العقوبات، بحث منشور

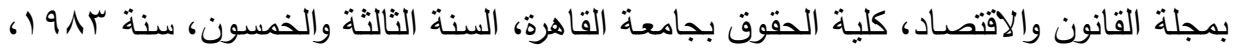

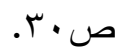

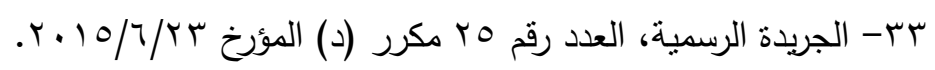




\title{
CHALLENGES OF CORRUPTION CRIMES AND TRACKING THEIR GAININGS IN THE LIGHT OF INTERNATIONAL DOCUMENTS AND
} EGYPTIAN LAW

\begin{abstract}
ABDU EI ASHRY
Given the secretive nature of such crimes, competent authorities face serious challenges to detect corruption crimes and confiscate the proceedings thereof. Those who commit such crimes protect their illegal interests and money by hiding them abroad. Therefore, this paper discusses the most important obstacles relevant to the detection of corruption crimes, tracking their gainings, and means of overcoming such obstacles.
\end{abstract}


IVo 